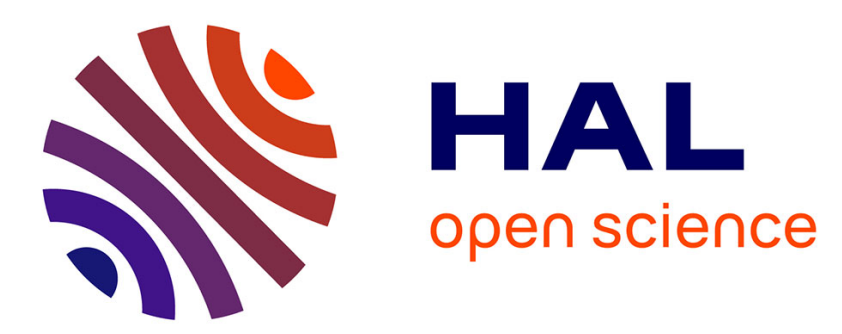

\title{
When the carbon being dated is not what you think it is: Insights from phytolith carbon research
}

\author{
Guaciara M Santos, Armand Masion, Anne Alexandre
}

\section{To cite this version:}

Guaciara M Santos, Armand Masion, Anne Alexandre. When the carbon being dated is not what you think it is: Insights from phytolith carbon research. Quaternary Science Reviews, 2018, 197, pp.162 174. 10.1016/j.quascirev.2018.08.007 . hal-01909878

\section{HAL Id: hal-01909878 https://hal.science/hal-01909878}

Submitted on 14 Dec 2018

HAL is a multi-disciplinary open access archive for the deposit and dissemination of scientific research documents, whether they are published or not. The documents may come from teaching and research institutions in France or abroad, or from public or private research centers.
L'archive ouverte pluridisciplinaire HAL, est destinée au dépôt et à la diffusion de documents scientifiques de niveau recherche, publiés ou non, émanant des établissements d'enseignement et de recherche français ou étrangers, des laboratoires publics ou privés. 


\title{
When the carbon being dated is not what you think it is: Insights from phytolith carbon research
}

\author{
Guaciara M. Santos ${ }^{\mathrm{a},}{ }^{*}$, Armand Masion ${ }^{\mathrm{b}}$, Anne Alexandre ${ }^{\mathrm{b}}$ \\ ${ }^{\text {a }}$ Earth System Science, University of California, Irvine, Irvine, CA, USA \\ ${ }^{\mathrm{b}}$ CEREGE, UM34, CNRS, Aix-Marseille Université, IRD, Coll France, INRA, Aix en Provence, France
}

\section{A R T I C L E I N F O}

\section{Article history:}

Received 31 December 2017

Received in revised form

27 July 2018

Accepted 3 August 2018

\section{Keywords:}

Phytolith occluded carbon

${ }^{14} \mathrm{C}$ dating

SEM-EDX

3D X-ray

NanoSIMS

Raman spectroscopy

DNP-NMR

${ }^{13} \mathrm{C}$ labelling

\begin{abstract}
A B S T R A C T
For proper interpretation of radiocarbon $\left({ }^{14} \mathrm{C}\right)$ age results, the carbon fraction being dated must be identified beforehand, ideally as a single homogeneous entity that best represents the event being studied. Radiocarbon dating of fossil phytoliths (biosilica formed in living higher-plants) has been used in a number of archaeology and paleoenvironmental studies. More precisely, the carbon occlusion (phytC) has been ${ }^{14} \mathrm{C}$ dated. This method relies on the phytC being photosynthetic in origin, so that its ${ }^{14} \mathrm{C}$ signature is similar to that of the host plant. However, we have recently presented overwhelming evidence that phytC in modern plants is made up of a mixture of carbon photosynthesized by the plant (from atmospheric $\mathrm{CO}_{2}$ ) and soil carbon comprised of multiple ${ }^{14} \mathrm{C}$ signatures (ages). The discussion presented here is based on our assessments of phytC ${ }^{14} \mathrm{C}$ signatures, their chemical nature, location, origin and fate as well as the current state of knowledge on plant cell silica interactions with biomolecules. Finally, regardless of the fact that there are cases where fossil phytc ${ }^{14} \mathrm{C}$ results appear to match expected values, the impossibility of establishing a priori either the amount of the soil carbon contribution to phytC or the mean ${ }^{14} \mathrm{C}$ age of its occluded mixed pool precludes the use of phytoliths as a reliable ${ }^{14} \mathrm{C}$ dating tool.
\end{abstract}

(c) 2018 Elsevier Ltd. All rights reserved.

\section{Introduction}

Phytoliths are micrometric hydrated silica particles that form inside and outside the cells of living plant organs. When they form in the cells, they take the shape of the cells and are assigned a taxonomic value (e.g. Piperno, 2006). After plant death, phytoliths can either dissolve and take part in the silicon cycle (e.g. Alexandre et al., 1994; Alexandre et al., 1999; Oleschko et al., 2004; Borrelli et al., 2010; White et al., 2012; Cornelis et al., 2014; Opalinska and Cowling, 2015) or be incorporated and preserved in soils, sediments or archaeological deposits (Cabanes et al., 2011; Gao et al., 2018). In the latter cases, the phytolith morphological assemblages can be used as paleoenvironmental or archaeological indicators, provided that the soil or sediment sequence is chronologically constrained and that taphonomic processes are taken into account (e.g. Nogué et al., 2017; Woodburn et al., 2017; Yost et al., 2018 for the most recent reconstructions).

Phytoliths trap trace elements, including carbon (phytC) in their

\footnotetext{
* Corresponding author

E-mail address: gdossant@uci.edu (G.M. Santos).
}

silica structure (Exley, 2015). The amounts of phytC reported by scholars vary, but are typically below $2 \%$. Hodson et al. (2008) suggested that variations are likely due to differences in the extraction methods and analytical techniques employed. Since high purity phytolith extracts are difficult to obtain, this assessment is probably correct even when only one protocol is being used. Assuming that this phytC is of photosynthetic origin, phytC ${ }^{14} \mathrm{C}$ extracted from living vegetation should have $\mathrm{a}^{14} \mathrm{C}$ signature similar to that of the host-plant, which in turn should reflect the ${ }^{14} \mathrm{C}$ signature of the ambient atmospheric $\mathrm{CO}_{2}\left(\mathrm{~atm}-\mathrm{CO}_{2}\right)$. This would imply that direct ${ }^{14} \mathrm{C}$ dating of fossil phytC ${ }^{14} \mathrm{C}$ offers the potential to determine a calendar age since the $C$ was encapsulated within the biosilica precipitate. Silica precipitates in cells over a period of a few hours (Kumar and Elbaum, 2017). While bulk phytolith assemblages extracted from plants reflect silica deposition throughout the life of the plant, bulk phytoliths extracted from soils, sediments or archaeological deposit are expected to reflect longer time spans (10s-100s of years), depending on accumulation rates and residence times.

The earliest attempt at direct fossil phytC ${ }^{14} \mathrm{C}$ dating appeared in an investigation of phytoliths accumulated in an Ohio soil 
developed in a riverine terrace (Wilding, 1967). Although the measured phytolith age was over 10,000 years older than the expected age, this article has been frequently cited as a proof-ofconcept of the reliability of phytC ${ }^{14} \mathrm{C}$ dating (e.g. Kelly et al., 1991; Sullivan et al., 2008; Sullivan and Parr, 2013; Carter, 2009; Piperno, 2006, 2016a; Zuo et al., 2017). In an attempt to reconstruct the American Great Plains paleo-vegetation, Kelly et al. (1991) measured $\delta^{13} \mathrm{C}$ and ${ }^{14} \mathrm{C}$ in fossil phytoliths. However, over $60 \%$ of these ${ }^{14} \mathrm{C}$ phytolith chronologies were biased-old (or inverted) by more than 3000 years (Santos, 2009). Kelly et al. (1991) acknowledged the phytc ${ }^{14} \mathrm{C}$ discrepancies and attributed them to remobilization effects. However, this work has also been cited in the literature as a proof of the reliability of phytolith ${ }^{14} \mathrm{C}$ dating (Carter, 2009 , for example). The interpretation of phytC $\delta^{13} \mathrm{C}$ data obtained from C3 and C4 plants have also been considered problematic. Webb and Longstaffe (2010) determined that C3 and C4 phytC $\delta^{13} \mathrm{C}$ data can overlap if preferential occlusion of plant molecular ${ }^{13} \mathrm{C}$ depleted compounds occurs.

In order to investigate whether phytoliths were indeed a proxy of plant $\mathrm{C}$ and atm- $\mathrm{CO}_{2}$, phytoliths from living vegetation harvested from different locations were extracted in distinct laboratories using conventional protocols and then measured by ${ }^{14} \mathrm{C}$ accelerator mass spectrometry (AMS) (Santos et al., 2010a). Whereas the data were expected to reflect contemporary atmospheric ${ }^{14} \mathrm{CO}_{2}$ levels from after the onset of thermonuclear testing in the middle 1950's (Hua et al., 2013), they showed systematic shifts towards several thousand years (Table 1 ).

Other post-bomb chronology studies have also presented ambiguous ${ }^{14} \mathrm{C}$ data. For instance, phytC ${ }^{14} \mathrm{C}$ dating of contemporary samples failed to adequately reproduce atmospheric values, e.g. the ${ }^{14} \mathrm{C}$-signatures of the bomb-pulse calendar years of harvesting. When trying to reproduce the bomb-peak using phytoliths extracted from mature bamboo and litter from samples collected on or before 2008, Sullivan et al., 2008, Sullivan and Parr, 2013) obtained ages thousands of years old ${ }^{14} \mathrm{C}$ for the most recent material (1.9 and 3.5 kyrs BP), while the litter phytC ${ }^{14} \mathrm{C}$ results yielded signatures that were mostly from or before the early 1950's. Even if the litter samples were not well characterized by direct isotopic measurements of their bulk organics, their ${ }^{14} \mathrm{C}$ profiles should be somewhat elevated due to post-bomb labeling (Carrasco et al., 2006). Still, the litter phytC ${ }^{14} \mathrm{C}$ data has been reported as "modern" (e.g. "post-bomb" by default - Sullivan and Parr (2013)). However, this does not necessarily constitute correctness. The application of post-bomb chronologies requires careful assessment of the results and the use of global ${ }^{14} \mathrm{C}$ atmospheric datasets (Hua et al., 2013) if the precise ${ }^{14} \mathrm{C}$ signature of the plant-host is unknown.
In another study, phytC ${ }^{14} \mathrm{C}$ results from Neotropical plants collected over multiple calendar years after 1950 were reported (Piperno, 2016a). However, the data did not match the ${ }^{14} \mathrm{C}$ bomb atmospheric inventories as expected. A modelling framework presented in Santos et al. (2016) indicates that such decadal to centennial phytoliths ${ }^{14} \mathrm{C}$ offsets are better resolved when plotted against best-fit curves calculated by applying different values of soil carbon (soil-C) turnover rates coupled with the temporal atm$\mathrm{CO}_{2}$ data after 1950 . Although some of those phytolith ${ }^{14} \mathrm{C}$ mismatches were explained by local and regional variations in atm$\mathrm{CO}_{2}$ emissions (Piperno, 2016b), no direct ${ }^{14} \mathrm{C}$ measurements of the collected plants have yet been reported to corroborate this assessment. Such large variations are extremely unlikely in regions with very low anthropogenic $\mathrm{CO}_{2}$ emissions (Hansen and Sato, 2016). Moreover, large discrepancies should have been apparent for other Neotropical biomass archives across the region (Dezzeo et al., 2003; Santos et al., 2016; Baker et al., 2017). Regardless, validation experiments using poorly or improperly characterized materials are pointless. A reanalysis of the data presented in Sullivan et al. (2008), Sullivan and Parr (2013) and Piperno (2016a) were presented in Santos et al. (2012a) and Santos et al. (2016), respectively. Additional present-day phytolith crossvalidation studies have also shown phytC ${ }^{14} \mathrm{C}$ anomalies (Yin et al., 2014; Reyerson et al., 2016; Asscher et al., 2017). Evidence was produced directly from phytolith extracts and plant-host pairs, and will be discussed in detail later.

After examining previous "too-old" or "age inversions" findings (Wilding, 1967, Kelly et al., 1991, Rieser et al., 2007, for example) misconstrued in the literature as demonstration of phytolith ${ }^{14} \mathrm{C}$ dating accuracy and reliability, and from the results shown in Table 1, we concluded that phytC had an unknown confounder that can bias its ${ }^{14} \mathrm{C}$ age(s) and that was not properly assessed in earlier investigations. The results shown in Table 1 are based on the intraand inter-laboratory investigations conducted by Santos et al. (2010a). A hypothesis was developed that phytC may include carbon that differs from the host-plant photosynthetic carbon. Specifically, it was hypothesized that soil-C acquired by plant roots may contribute to phytC and bias the phytC ${ }^{14} \mathrm{C}$ results towards unexpected values (Santos et al., 2012b). This hypothesis was based on previous evidence of direct root uptake from the rhizosphere by higher plants and upward translocation of organic compounds such as sugars, amino acids, organic acids, fatty acids, urea, quaternary ammonium compounds, as well as other nitrogenous substances. This evidence have been accumulating in the literature since the late 1950's (see findings and references compiled in Jones et al., 2009, Paungfoo-Lonhienne et al., 2008, 2010, 2012, Warren, 2013, Pinton et al., 2016, Zhalnina et al., 2018).

\section{Table 1}

Averaged fraction modern ${ }^{14} \mathrm{C}\left(\mathrm{Fm}^{14} \mathrm{C}\right)$ values and uncalibrated ${ }^{14} \mathrm{C}$ ages of phytoliths extracted from modern grasses clippings at different locations. Ages reported herein are uncalibrated years B.P. (years before present). Present-day corresponds to ${ }^{14} \mathrm{C}$ results that matched the expected ambient ${ }^{14} \mathrm{CO}_{2}$ signatures of the harvesting year. Individual uncertainties can be attributed to counting statistics, spectrometer isotopic fractionation, and scatter of results from primary and secondary standards, and most importantly, background corrections attained from chemical extraction blanks. The complete dataset, including blank determinations was reported in Santos et al. (2010a).

\begin{tabular}{lll}
\hline Sample location & Sample type & $\mathrm{Fm}^{14} \mathrm{C}^{\mathrm{a}}$ \\
\hline Crop field - & Grass clipping & $1.0490 \pm 0.0020(\mathrm{n}=2)$ \\
CEREGE, France & Phytolith extracts & $0.7790 \pm 0.0041$ \\
& & $0.7505 \pm 0.0178$ \\
& & $0.7306 \pm 0.0620$ \\
& & $1.0605 \pm 0.0011(\mathrm{n}=2)$ \\
Rural area - & Grass clipping & $0.5370 \pm 0.0090$ \\
Minnesota, USA & Phytolith extracts & $1.0546 \pm 0.0050(\mathrm{n}=2)$ \\
Rural area - & Grass clipping & $0.3677 \pm 0.0254$ \\
Madison, USA & Phytolith extracts & Present-day \\
\hline
\end{tabular}

${ }^{\mathrm{a}} \mathrm{n}$ represents the number of individual measurements performed on grasses. Clipping indicates a small section cut off of a mature stem or leaf of about $2-3 \mathrm{~cm}$ maximum used as reference for the host plant ${ }^{14} \mathrm{C}$ signature, after a light chemical cleaning and measurement.

b Where applicable, numerical results are reported as average \pm standard deviation. 
Subsequently, a comprehensive and systematic investigation was undertaken on the ${ }^{14} \mathrm{C}$ signatures of the phytC atm- $\mathrm{CO}_{2}$ and soil-C fractions (bulk, labile and recalcitrant) potential sources (Reyerson et al., 2016). The heterogeneity of the phytC pool was examined using chemical and thermal oxidation apportionment followed by ${ }^{14} \mathrm{C}$ measurements of its fractions. In order to avoid any assumptions concerning how soil-C may end-up in phytoliths and how phytoliths encapsulate and stabilize C, a detailed study of phytolith structure, phytC nature, origin and translocation in plants was also conducted. These findings were discussed in detail in several different papers (Alexandre et al., 2015, 2016; Gallagher et al., 2015; Masion et al., 2017). The results clearly demonstrated that soil-C can be absorbed by plant roots and at some extent incorporated into phytoliths (e.g. it is a fraction of phytC).

However, given that recent studies have attempted to revive the archaeological phytC ${ }^{14} \mathrm{C}$ dating methodology (Zuo et al., 2016, 2017; Asscher et al., 2017), a brief review of our main findings are presented. We also summarize the recent phytC ${ }^{14} \mathrm{C}$ dates in the literature. We focus on those studies that attempted to validate the phytC as a plantC proxy. Our intent is to make sense of the collection of studies reviewed, regarding extraction processes versus ${ }^{14} \mathrm{C}$ results, and to clarify misleading speculations on the cause of the skewed phytolith ${ }^{14} \mathrm{C}$ results, such as that they are due to flaws in the phytolith extraction protocols, rather than its complex carbon mixture (photosynthetic and soil-C). As heterogeneous $\mathrm{C}$ pools have a large age spectrum (Voort et al., 2016) with complex chemical reactivity, they are likely to respond differently to different oxidative treatments. Precise and accurate age determinations are not easy to make. Finally, we make comparative analysis of our remarkable findings with those in the literature supporting the intake of soil-C compounds by plants, the current knowledge on biomolecule-biosilicification precipitates, Si-cell interactions, cell-to-cell communications and biosilicification processes, to help scholars to stay relevant, and be more careful when interpreting phytolith results. Particular emphasis was placed on recent studies presenting evidence that organic compounds from soils are metabolized by plants, and how those compounds may end up trapped in phytoliths.

\section{Assessment of phytolith extracts purity and chemical interference during extractions}

For phytolith morphological identification under light optical microscopy, the purity of phytolith extracts is not critical and several phytolith extraction protocols, described in the literature, have been designed to isolate phytoliths from the surrounding plant tissues or from soils and sediments (synthesis in Corbineau et al., 2013). For phytC analysis, where minute $C$ contamination can distort results, "pristine" chemical extractions and purity evaluations are indispensable tools.

Traditionally, the purity of the final phytolith extracts has been assessed by light optical microscopy. While this method is sufficient for determining phytolith morphological types, it is not sufficient to help on detecting microscopic OC residues that are the product of incomplete oxidative digestions. The organic residues can come from the host-plants or from the soils or sediments, depending on the type of sample analyzed (Santos et al., 2010a, 2012b). Such residues can lead to phytC concentration overestimation (e.g. higher than $0.1-1 \%$ dry weight; Smith and White, 2004) and isotopic bias (Santos et al., 2012b; Santos and Alexandre, 2017). Scanning Electron Microscopy (SEM) equipped with Energy Dispersive X-Ray Analysis (EDX) is thus highly recommended to verify phytolith extract purity (Corbineau et al., 2013) before performing phytC quantitative, isotopic or spectroscopic analyses. The method is robust but not infallible, as it cannot discriminate minute carbon attached to phytolith surfaces.

Fourier transform infrared spectroscopy (FTIR) techniques, traditionally used in materials characterization in industry and recently applied to organic compound assessment of sediments (Lindon et al., 2016), has also being used to evaluate fossil-phytolith sediment characteristics and phytolith extract purity (Asscher et al., 2017 and references therein). While useful, the technique is limited to high $\mathrm{C}-\mathrm{O}$ or Si-C peaks and cannot easily discriminate minute amounts of $C$ impurities in extracts either. Indeed, while FTIR is capable of detecting a given compound in the \%o-ppm range depending on instrumentation set-up, optical path length, duration of analysis, such values can be detected only under "ideal" conditions (e.g. Hebert et al., 2004; Sessa et al., 2011). However, since FTIR is not an element specific spectroscopy, there might be an overlap between the signal of the substance and the signal of the matrix, thereby making the detection more difficult and shifting its limit towards significantly higher concentrations. This situation becomes particularly unfavorable in the presence of a mineral matrix since inorganics usually have strong peak intensities compared to organics to the point that even minor amounts of inorganics can render the organic fraction undetectable (VilgéRitter, 1997).

At present SEM-EDX and FTIR have been used to evaluate the presence of organic matter impurities in phytolith extracts from a) plants (residues from the host-harvested material), or b) soils/ sediments (residues from the surrounding of fossil phytolith). Proper characterization of trapped carbon in phytolith (i.e. phytC) would require dissolution of silicate beforehand.

Another issue commonly overlooked in phytC ${ }^{14} \mathrm{C}$ age determinations is the lack of proper control samples (such as chemical processing blanks) during the phytolith extractions. It is important do not confuse running blank and standards of ${ }^{14} \mathrm{C}$ sample processing alone (Zuo et al., 2017), applied by all labs in the community, with procedural blanks undergoing chemical phytolith extractions (Santos et al. 2010a; Reyerson et al. 2016). While ${ }^{14} \mathrm{C}$ free material analogous to the sample under investigation would be ideal for blank assessment (Santos et al., 2010b), phytolith of more than 55 kyrs BP cannot be found in large enough quantities for ${ }^{14} \mathrm{C}$ analyses. Indeed, a large portion of phytoliths is rapidly dissolved in litter, soils and surface waters and participates in the silicon cycle (synthesis in Opalinska and Cowling, 2015). Nevertheless, chemical background correction is an essential part of ${ }^{14} \mathrm{C}$ analysis (Santos et al., 2010b) and cannot be limited to target preparation (e.g. combustion and graphitization, for example). Chemicals must be evaluated, as manufacture purity labels are not an absolute guaranty of the absence of organic carbon (OC). For example, sodium polytungstate, commonly used for the isolation of pollen, and sometimes of phytoliths (e.g. Piperno, 2006; Asscher et al., 2017) is known to contain minute amounts of organics (Prior et al., 2011). Organic solvents can also bond to phytoliths, as demonstrated in Santos et al. (2010a). In the absence of a sample-specific background material, we subjected $\mathrm{SiO}_{2}$ powder to all stages of sample extraction and processed it alongside of phytolith targets every time they were isotopically measured. All ${ }^{14} \mathrm{C}$ data presented in Table 1 supporting the soil-C contribution to phytC hypothesis (Santos et al., 2012a; Reyerson et al., 2016) were background corrected this way (further details are described in Santos et al., 2010a,b).

While nowadays we consider the purity evaluation of phytolith extracts by SEM-EDX crucial, the method was not implemented until after measuring the phytolith extracts leading to the ${ }^{14} \mathrm{C}$-AMS data reported in Table 1 . Standard best-practices at the time of phytolith extraction purity evaluations, called for optical 
microscope screening (Santos et al., 2010a). Thus, the older phytC ${ }^{14} \mathrm{C}$ ages found for the phytolith extracts from living plant-hosts in Table 1 might be due in part to the contribution of organic plant tissue residues (Fig. 2 in Santos et al., 2012b) left by the chemical standard protocol chosen at the time of extractions took place. If recalcitrant portions of the soil-C continuum (once internalized in the living plant through acquisition of organic nutrients by their roots and randomly distributed in plant compartments) were not properly removed during the plant tissue chemical oxidation (Harvey et al., 2012), they would augment both the phytC\% and ${ }^{14} \mathrm{C}$ offsets. Given the highly depleted phytC ${ }^{14} \mathrm{C}$ age results of Table 1 and our observations of organic residues in Fig. 2 in Santos et al. (2012b), which cannot be attributed to a blank issue, all subsequent phytolith extracts were screened by SEM-EDX prior to the quantitative, structural, spectroscopic and isotopic analyses.

\section{Phytolith structure and phytC location}

Phytolith-colored pigmentation and opaque spots visible on optical-microscopy examination have been interpreted frequently as in vivo OC occlusions. A representation of how OC becomes occluded during silicon biomineralization leading to those distinctive opaque spots has been offered by Carter (2009). However, a combination of nanoscale secondary ion mass spectrometry (NanoSIMS) and three-dimensional X-ray microscopy analyses of individual phytoliths has shown that these opaque spots are just images of empty cavities (Alexandre et al., 2015). Recent data acquired from fluorescent confocal microscopy suggest that these voids were originally occupied by the cell cytoplasm, which likely faded rapidly during cell death (Kumar et al., 2017). Furthermore, because the inner voids can be connected to the phytolith surface, i.e. open to the outside (Fig. 1), even if this pool of phytC is preserved in the cavities after death cell, it would be susceptible to oxidation when phytoliths enter litter and soil (Alexandre et al., 2015).

NanoSIMS scans of biosilica solid sections clearly reveal the presence of a second phytC pool continuously distributed in the silica structure (Alexandre et al., 2015). The spectral mapping by Stimulated Raman Scattering (SRS) microscopy of single grass phytoliths also showed that organic matter is distributed unevenly throughout the biosilica structure, and not necessarily concentrated into the small dark spots as one might expect from the optical microscopy mirrored images (Fig. 2 in Gallagher et al., 2015). The high nitrogen content of the phytC pool throughout the biosilica observed by Alexandre et al. (2015) suggested the presence of amino acids.

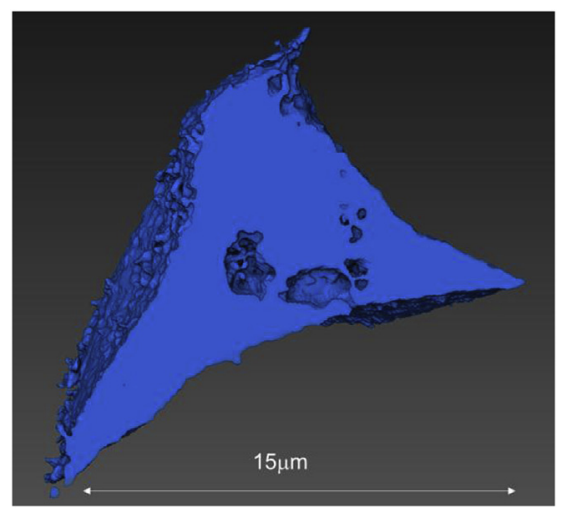

Fig. 1. Three-dimension reconstruction of a grass short cell phytolith structure using micro-scale X-ray imaging and the software XMReconstructor. It shows internal cavities connected to the outside. From experiments described in Alexandre et al. (2015).

\section{Molecular characterization of phytC}

In an effort to investigate variability in phytC composition, SRS analyses were performed on phytoliths extracted from a unique grass species (Sorghum bicolor) grown under same atm- $\mathrm{CO}_{2}$ conditions, but different bulk C-substrates (carbon signatures determined by ${ }^{14} \mathrm{C}$ analysis were reported in Reyerson et al., 2016). These analyses showed shifts in the stretching modes of $\mathrm{C}-\mathrm{H}$ bonds from one sample to another suggesting different molecular composition of phytC as a result of different belowground $C$ treatments, or in some cases, different plant primary metabolic responses (Gallagher et al., 2015). There can be little doubt that the variability of the SRS spectral signatures were not related to differences on phytolith extraction procedures (contrary to the assertions in Watling et al., 2011), as just a single phytolith chemical extraction protocol (wet oxidation protocol 1a) was followed (Reyerson et al., 2016; Table S3 in Supplement). PhytC spectral peaks in Gallagher et al. (2015) suggested the presence of proteins, carbohydrates and lignins. The data from Gallagher et al. (2015) and Alexandre et al. (2015) motivated pursuit of more direct approaches for characterizing phytC.

Nuclear magnetic resonance (NMR) exploits the magnetic properties of ${ }^{13} \mathrm{C}$ and ${ }^{1} \mathrm{H}$, allowing the detection of $\mathrm{C}$-compounds such as proteins (made of amino acids) and nucleic acids. When NMR is coupled with dynamic nuclear polarization (DNP) it results in an enhancement of the NMR signal by several orders of magnitude, allowing the measurement of phytC in minute concentrations (\%o to \% concentrations). In our case, phytC\% of very pure phytolith extracts was in the order of $0.1 \%$. Phytolith extracts harvested from plants grown in natural soils and with sufficient irrigation were analyzed (Masion et al., 2017). DNP-NMR revealed a large variety of phytC-compounds (i.e., alkyl, carbohydrates, carbonyl, alkyl-N, and aromatics). The variety of phytC molecules observed was consistent with previous results showing different levels of resistance to oxidation when phytC was exposed to a multi-step thermal treatment (Reyerson et al., 2016). Additionally, the presence of alkyl, alkyl-N and carbonyls revealed by the DNP-NMR (Fig. 2) was consistent with a significant proportion of peptides (half of the detected NMR signal), i.e. well beyond typical protein proportions for wheat leaf tissue. Peptides are likely fed by the soil-C pool accumulated in the biosilica structure that is accessible in isotopic or spectroscopic analyses of pure phytolith extracts. This result supports the assumption of a soil-C contribution to phytC.

\section{Evidence of carbon absorption by roots and its translocation into phytoliths}

The uptake of low-molecular-weight $\mathrm{C}$ and $\mathrm{N}$ by plant roots has been well documented (see references in Alexandre et al., 2016) through labeling experiments. In order to investigate whether soil$\mathrm{C}$ absorbed by roots can end up occluded in phytoliths, a grass species (Festuca arundinacea) was grown in a hydroponic solution enhanced with silica and ${ }^{13} \mathrm{C}$ and ${ }^{15} \mathrm{~N}$ labeled amino acids, and no other carbon-based fertilizer. The above biomass was physically separated from the roots and the hydroponic culture by a membrane until harvesting (after 14 days of growth). Stems and leaves were analyzed by dry combustion-elemental analysis-isotope ratio mass spectrometry (C-EA-IRMS) and the phytoliths by EA-IRMS. Data from labeled pots were compared to those from unlabelled pots. The data showed that a portion of the amino acid-derived ${ }^{13} \mathrm{C}$ was absorbed and translocated into the plant in its original amino acid form. Amino acids-derived ${ }^{13} \mathrm{C}$ was detected in phytoliths. Its concentration was very low but was of the same order of magnitude as in the stems and leaves ( $0.15 \%$ of total $C)$. This labelling experiment may underestimate the extent of the uptake of amino 


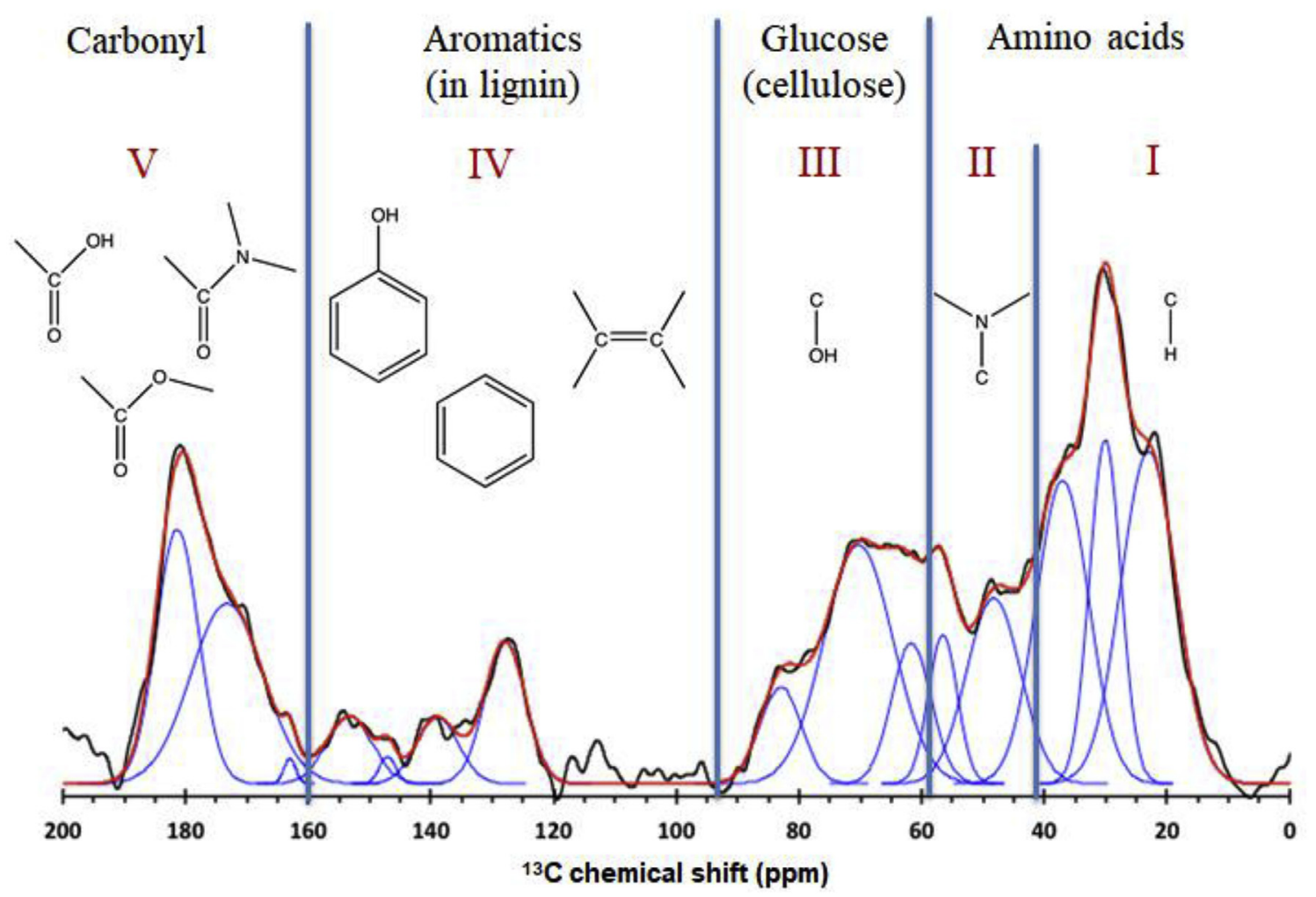

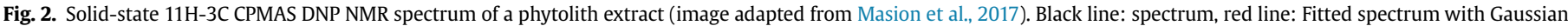

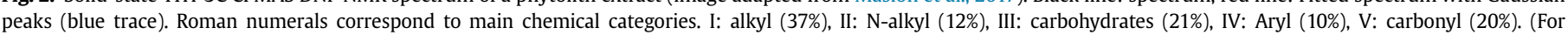
interpretation of the references to color in this figure legend, the reader is referred to the Web version of this article.)

acids by plants under natural and field conditions for two reasons: i) amino acids uptake can be inhibited by the high concentrations of mineral nitrogen (Gioseffi et al., 2012; Paungfoo-Lonhienne et al., 2008; Sauheitl et al., 2009). In the experiment, mineral nitrogen came from $\mathrm{KNO}_{3}$ and likely from the supplied amino acids dissociated by microbes, mycorrhizas or root exudates; and ii) the roots were in contact with a limited volume and number of amino acids. While the abundance of organic nitrogen compounds in soils may vary by soil type, they still can be on the order of thousands (Watkinson, 2016). Still, the experiment unambiguously proved that external organic amino acids can enter the plant through the roots, and ultimately feed phytC.

\section{Impact of the phytC carbon mixed pool on phytC ${ }^{14} \mathrm{C}$ signatures}

Our early study on ${ }^{14} \mathrm{C}$ results from phytoliths extracted from freshly harvested grasses (Table 1), using a protocol adapted from those available in the literature (e.g. Kelly et al., 1991, Piperno, 2006, 2016a), indicate that phytC must consist of a mixed pool of $C$ composed of photosynthetic atm- $\mathrm{CO}_{2}$ and soil- $\mathrm{C}$. Since soil- $\mathrm{C}$ is a heterogeneous mixture with unique distributions of labile and recalcitrant $C$ fractions of multiple ages, its fractions are susceptible to apportionment by different levels of oxidation.

In order to systematically test the soil-C contribution to phytC hypothesis (Santos et al., 2012b), phytoliths were subjected to different degrees of oxidation (Corbineau et al., 2013; Reyerson et al., 2016) and measured by ${ }^{14} \mathrm{C}$-AMS. We made use of freshly harvested grasses of known age. The ${ }^{14} \mathrm{C}$ signatures of the potential sources of $\mathrm{C}$ (atm- $\mathrm{CO}_{2}$ and soil-C) during the growing season were also controlled. One experiment regulated the ${ }^{14} \mathrm{C}$ of atm- $\mathrm{CO}_{2}$ injected on plants above-ground (Free-Air $\mathrm{CO}_{2}$ Enrichment - FACE - experiment), while the second experiment controlled the ${ }^{14} \mathrm{C}$ signatures of solutes below-ground (soil with organic amendments of known and distinct mean ages), as exemplified below.

In Fig. 3 we plot the results of just one of the above-ground FACE manipulation experiments reported in Reyerson et al. (2016). In this subset, sorghum plants were subjected to fossil $\mathrm{CO}_{2}\left({ }^{14} \mathrm{C}\right.$-free $)$ during the entire growing season of 1999 , whereas a control plot was exposed to ambient atm- $\mathrm{CO}_{2}$. No other experimental conditions were imposed, except sufficient irrigation. All carbonaceous materials associated with this experiment, namely the bulk plant tissue, soil-C (both the labile and recalcitrant fractions) and phytolith extracts were isotopically tested for $\delta^{13} \mathrm{C}$ and ${ }^{14} \mathrm{C}$ signatures. As expected, the bulk grass tissue from the FACE (fossil) plot yielded a ${ }^{14} \mathrm{C}$ signature with an age equivalent to $3,5 \mathrm{kyrs} \mathrm{BP}$, while the bulk grass tissue from the control plot matched with the atm- ${ }^{14} \mathrm{CO}_{2}$ value for the calendar year 1999 . With regard to phytoliths, the least aggressive extractions (i.e. protocol 1a on Fig. 3, upper panel) occasionally resulted in phytC ${ }^{14} \mathrm{C}$ signatures similar to those of bulk grass tissues. However, when the extraction aggressiveness increased (i.e. protocols $1 \mathrm{~b}, 2 \mathrm{a}, 2 \mathrm{~b}$ on Fig. 3 ), the phytC ${ }^{14} \mathrm{C}$ signatures systematically tended towards the mean age of the SOC. The Labile and recalcitrant fractions of SOC yielded C turnover rates of 3 and 8 kyrs BP, respectively. This clearly demonstrated that soil-C is part of phytC, as its relative proportion became apparent with increased oxidation (i.e., loss of labile carbon). A phytC continuum was also demonstrated to exist by subjecting phytolith extracts to a stepwise temperature ramp from 50 to $850^{\circ} \mathrm{C}$ under pure oxygen (Fig. 6 in Reyerson et al., 2016). The evolved $\mathrm{CO}_{2}$ appeared as early as $150{ }^{\circ} \mathrm{C}$ and was continuously emitted for each step of temperature rise, until complete exhaustion at $850^{\circ} \mathrm{C}$, showing that phytC contains different decomposability proprieties.

In the below-ground manipulation experiments, grasses were 


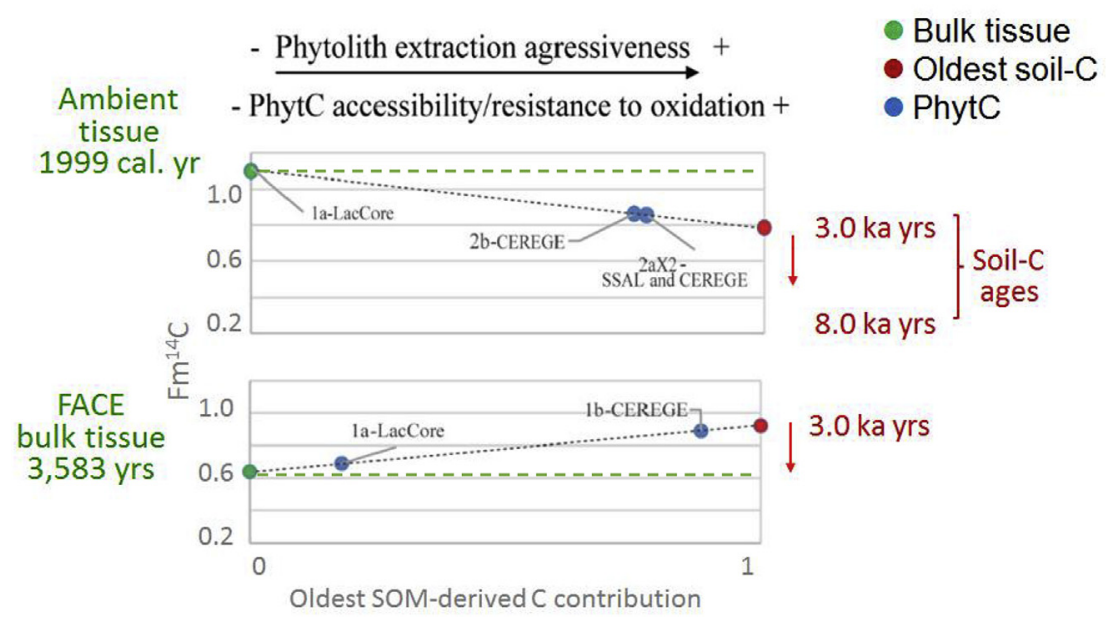

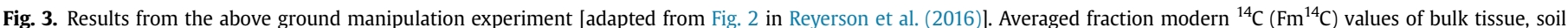

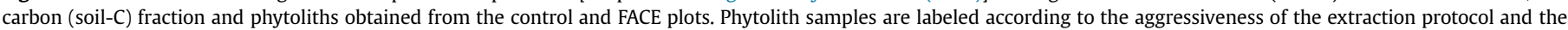

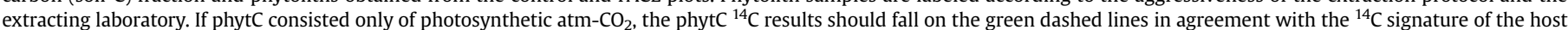

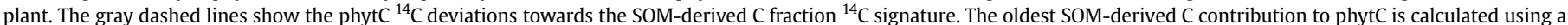

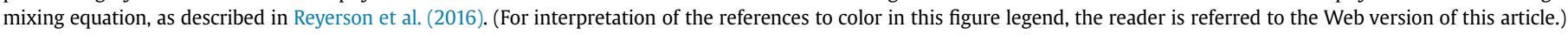

grown under identical atmospheric conditions on soil substrates fed with $C$ amendments with mean ages varying from post-bomb (2003-2008 calendar years) to 43 kyrs BP. The experimental design took into consideration a multifactor approach, so as to eliminate ambiguous interpretations. Besides ${ }^{14} \mathrm{C}$ measurements of plant-phytolith pairs, we also monitored air- $\mathrm{CO}_{2}$ samples collected in a $6 \mathrm{~L}$ cylinder alongside the planters to uncover isotopic variabilities during the growing season. Concentrations and isotopic values of soil-respired $\mathrm{CO}_{2}$ samples collected in molecular sieves were determined at the onset of vegetation sprouting. Biomass was harvested from mature plants before flowering. Phytoliths were extracted using the same set of protocols as described in Corbineau et al. (2013) and Reyerson et al. (2016). Here, we plot only a subset of the data produced, e.g., the phytC ${ }^{14} \mathrm{C}$ results from our least aggressive procedure to obtain pure phytolith extracts (the single wet-digestion protocol 1a). During extractions, chemicals were applied in tandem to all plant-parts, so that phytolith extracts would be equally affected by the chemicals and their relative strengths. Thus, the issue of the possible inconsistency of the ${ }^{14} \mathrm{C}$ age associated with the susceptibility of phytC to oxidation stress from chemicals or thermal reactions would be avoided. Pure phytolith extracts were measured by EA-IRMS for their phytC\%. Once phytC\% was established, phytolith samples and $\mathrm{CuO}$ were stoichiometrically calculated and weighed out to produce graphite targets of equal/even sizes. This protocol ensured that graphite targets were significantly large and the background corrections applied to ${ }^{14} \mathrm{C}$ results were of similar amplitude.

A strong correlation was obtained between the ${ }^{14} \mathrm{C}$ values of the soil- $\mathrm{C}$ or amendments and the ${ }^{14} \mathrm{C}$ values from phytC, except for Planter C (Fig. 4). The phytC ${ }^{14} \mathrm{C}$ offsets confirmed that phytC partly came from soil-C. PhytC ${ }^{14} \mathrm{C}$ offsets were in both directions, i.e. it was biased positive when the amendment contained post-bomb $C$ enriched in ${ }^{14} \mathrm{C}$ caused by above-ground nuclear testing after 1950 (Planter $\mathrm{A}$ ), and biased negative when the amendment contained pre-bomb/ancient carbon compounds (Planters B-E). Although the carbon-amendment added biweekly to Planter $\mathrm{C}$ was relatively depleted in ${ }^{14} \mathrm{C}$ (bulk value yielded 26 kyrs BP), its overall concentration per litter was likely too low to bias phytC ${ }^{14} \mathrm{C}(<0.02 \mathrm{~g} /$ liter per feeding). Radiocarbon results from plant-clippings of approximately $2 \mathrm{mg}$ of dry weight per combustion did not indicate detectable amounts of soil- $\mathrm{C}$, and were on average $\left(\mathrm{Fm}^{14} \mathrm{C}=1.02\right.$;

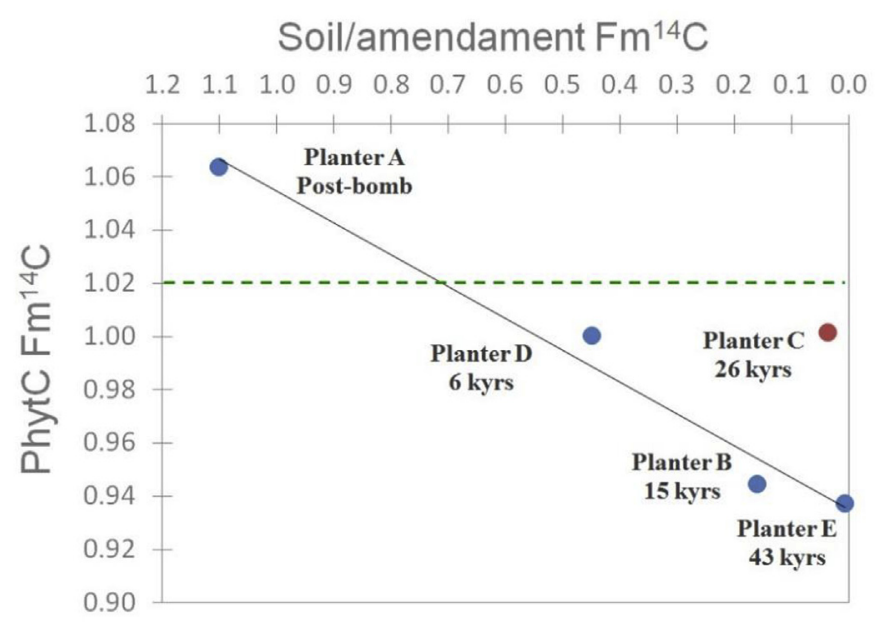

Fig. 4. Subset of results from the below-ground manipulation [adapted from Fig. 4 in Reyerson et al. (2016)]. PhytC Fm ${ }^{14} \mathrm{C}$ offsets (highlighted in blue) are linearly correlated (gray line) to the $\mathrm{Fm}^{14} \mathrm{C}$ signatures of the soil carbon amendment, except for Planter $\mathrm{C}$ (highlighted in red). The mean ${ }^{14} \mathrm{C}$ ages in kyrs BP of the carbon pool in the amendments are shown in labels, except for Planter $\mathrm{A}$, which received an amendment imprinted with ${ }^{14} \mathrm{C}$ post-bomb values (e.g. $\mathrm{Fm}^{14} \mathrm{C}$ higher than present-day). The green dashed line shows the average value of the ${ }^{14} \mathrm{C}$ signature of host plants. (For interpretation of the references to color in this figure legend, the reader is referred to the Web version of this article.)

dashed line in Fig. 4). Radiocarbon signatures from the respired$\mathrm{CO}_{2}$ gathered after sprouting were also measured and found to be irrelevant (not shown here). Therefore we suspected that the phytC ${ }^{14} \mathrm{C}$ offsets (Fig. 4) were in part due to the $\mathrm{C}$ absorbed by the roots, likely originating from the planter-specific belowground $C$ treatments applied to Planters A-E (Reyerson et al., 2016), as indicated as well by SRS (Gallagher et al., 2015). Although the experiment used a small but representative subset of solutes of organic and inorganic forms commonly used in soils, they were applied as bulk $\mathrm{C}$ and therefore we were unable to determine the preferred or dominant carbon-containing compound group(s) selected per root-plant treatments (e.g. proteins, carbohydrates, aromatics and/or lignins).

The results in Fig. 4 clearly demonstrated that soil- $C$ can be absorbed by plant roots and trapped in phytoliths (at percentages 
as high as $10 \%$, in pure phytolith extracted using the least aggressive protocol 1a - Reyerson et al., 2016), giving to phytC an apparent ${ }^{14} \mathrm{C}$ age of $\sim 700$ years too old, if offsets are translated into pre-bomb years. This fact throws into question the assumption that phytC is a proxy of plant $C$, as phytC is clearly heterogeneous in nature. In short, this subset of experimental phytC ${ }^{14} \mathrm{C}$ results strongly illustrated the dangers of using phytC as a dating material. Offsets were detected when the least aggressive extraction procedure was applied. And, as any other mixed age carbon pool with an operationally defined split point, an increase of its apparent recalcitrant aged pool can immediately result in larger ${ }^{14} \mathrm{C}$ offsets, as we illustrated earlier (Fig. 3).

At the other end of the spectrum, insufficient cleaning of phytolith extracts before analysis can also pose a problem. The largest ${ }^{14} \mathrm{C}$ age offset recorded from phytoliths when using present-day plant material and conventional phytolith extraction protocols, similar to those described in Kelly et al. (1991) and/or Piperno (2006, 2016a), exceeded 8 kyrs BP (Table 1, Santos et al., 2010a). From the total phytC\% estimated and ${ }^{14} \mathrm{C}$ signal measured, this phytolith extract alone had over $60 \%$ of depleted ${ }^{14} \mathrm{C}$, likely soil $\mathrm{C}$, as all other potential sources were ruled out. This age result mirrors other such 'thousand years old' results already mentioned above. Since temporal bulk soil organic carbon (SOC) ${ }^{14} \mathrm{C}$ age differences have been found to be comparable even at the lowest levels within soil profiles (Voort et al., 2016), it is reasonable to assume that living Holocene plants could also uptake singlet soil-C compounds of multiple ages at any time-frame (Voort et al., 2017), and incorporate them into phytoliths. Therefore, phytc alone should not be considered as dating material for archaeological purposes.

Unfortunately, natural phytC $\delta^{13} \mathrm{C}$ data alone cannot directly distinguish atm- $\mathrm{CO}_{2}$ from soil- $\mathrm{C}$ compounds in plants. Once the photosynthetic pathways transform atm- $\mathrm{CO}_{2}$ into glucose, amino acids, and organic acids, and the plant catabolizes (breakdown) them for further use (Hildebrandt et al., 2015), the $\delta^{13} \mathrm{C}$ signature of their summation would be rather similar to the total organic solute compounds taken from the rhizosphere by plants. Both would be catabolized by the plant-host in the same fashion (Pinton et al., 2016 and references therein). Note that SOC is mostly produced from above-biomass material decomposed by micro-organisms living in soils (Zeller et al., 2007). Its $\delta^{13} \mathrm{C}$ signatures would be somewhat similar to those of plants (Voort et al., 2017), and as such, would overlap with each other. However, in order to rule out the possibility of isotopic fractionation anomalies affecting phytC ${ }^{14} \mathrm{C}$ data, phytC $\delta^{13} \mathrm{C}$ signatures were measured. No such fractionation anomalies were found. The $\delta^{13} \mathrm{C}$ values of phytoliths were consistent with plant- $\mathrm{C}$ and the plant-derived soil-C signatures, as expected. The averaged phytC $\delta^{13} \mathrm{C}$ values $(-19.4 \pm 1.2 \%$; $n=5)$ fall within the carbon isotope signature range for phytoliths extracted from C4 plants, which is typically lighter (Smith and White, 2004). Although the inorganic $C$ pool in Planter $B$ amendment makes up $40 \%$ of its total $C$, the $\delta^{13} \mathrm{C}$ signatures of its phytC $(-19.1 \%)$ suggested that no significant amounts of inorganic $C$ contributed to the phytC pool. The complete dataset, with over 200 isotopic results, is reported in Reyerson et al. (2016; Supplement).

\section{Discussion}

Despite the obvious overlap in content and implications, we will refrain from commenting on the extent of atm- $\mathrm{CO}_{2}$ phytosequestration since this has been covered elsewhere (Santos and Alexandre, 2017).

\subsection{Coexistence of distinct sources of carbon within plant tissues}

To better understand the soil-C biasing of phytC ${ }^{14} \mathrm{C}$, it is important to consider how soil-C is first mobilized by plant-root and then catabolized within the tissue. Several nutrients are essential for plant growth and health. As previously noted, root absorption of organic nitrogenous compounds with or without the assistance of mycorrhizal fungi has been well documented in plant organs and cells (Rentsch et al., 2007; Näsholm et al., 2009; Jones et al., 2009; Sauheitl et al., 2009; Whiteside et al., 2009; Paungfoo-Lonhienne et al., 2008, 2010, 2012; Warren, 2013; Pinton et al., 2016; Zhalnina et al., 2018) and recently in phytoliths (Alexandre et al., 2016). Even plant intake of some aromatics from soils has been reported by scholars due to its importance in soil toxicity remediation (Bouchereau et al., 2000; Gao and Zhu, 2004; Gao et al., 2011, 2013; Alagić et al., 2016; Jajoo, 2017). Microbes can assimilate ancient aromatic compounds as well (Petsch et al., 2001), including polyaromatics, and therefore a contribution of minute fossil- $\mathrm{C}$ to the plant system is possible. Thermal resistance to oxidation coupled with increased depleted (older) phytC ${ }^{14} \mathrm{C}$ values have been observed in phytoliths from living vegetation (Yin et al., 2014; Reyerson et al., 2016), and suggest the presence of high levels of aromaticity. Several analytical tools and modes of observation have been used to evaluate organic solute treatments and their translocation into plants, including radioisotopes (Stemmet et al., 1962), Scanning Electron Microscopy (SEM), Transmission Electron Microscopy (TEM) or bright field imaging (Lin et al., 2009; Liu et al., 2009; Tripathi et al., 2011), amino acid labelling (Weigelt et al., 2005; Näsholm et al., 2009), fluorescent-labeled microorganisms (Paungfoo-Lonhienne et al., 2010), quantum-dots (Whiteside et al., 2009, 2012), among many others. Even plant photo-assimilates produced in the leaves can be exchanged between specimens via the rhizosphere, likely with the assistance of ectomycorrhizes (Klein et al., 2016). While a detailed discussion on the degradation of nitrogenous compounds, e.g. the dissociation of their carboxyl and amino groups in the context of plant cell physiology, is beyond the scope of this paper; instead, we refer the reader to the works of Hildebrandt et al. (2015) and Pinton et al. (2016).

Several mechanisms for plant uptake of organic compounds from soils have been proposed (Jones et al., 2009). The process cannot be without its costs to the plant, and therefore likely varies depending on plant species and demands, as well as the available $\mathrm{C}$ and $\mathrm{N}$ amounts in the rhizosphere. In the framework of the belowground experiment previously described (Reyerson et al., 2016 and Fig. 3), the very low amount of solute carbon added in amendment of Planter $C$ per treatment $(<0.02 \mathrm{~g} /$ liter biweekly) may explain why no significant phytC ${ }^{14} \mathrm{C}$ offset was detected. While the extent and the molecular diversity of the soil-C contribution to plants is still to be fully characterized the coexistence of distinct sources of $C$ within plant tissues and phytC is understandable. As a consequence, there is no a priori way to correct phytC ${ }^{14} \mathrm{C}$ values for the soil-C contribution, as recently proposed (Yin et al., 2014), because this contribution may change from one context to another.

\subsection{Asymmetric ${ }^{14} \mathrm{C}$ effects of soil-C contribution to plant material and phytC}

Since it has been established that plants can acquire carbon from soils, the next question is 'why doesn't soil- $C$ affect the ${ }^{14} \mathrm{C}$ ages of organics in general (such as plant remains or tree rings)?' The coexistence of different ${ }^{14} \mathrm{C}$ ages in plant organs, associated with $\mathrm{C}$ metabolites of structural or non-structural pools, has long been known. Radiocarbon analyses of chemically untreated tree ring wood of known calendar years have shown a bias towards older ${ }^{14} \mathrm{C}$ values, e.g. C from previous years (e.g. Cain and Suess, 1976; Tans et al., 1978; Worbes and Junk, 1989). At least a fraction of this slightly older pool of $C$ is non-structural labile carbon (10-20\%), i.e. 
mostly sugars and starches that the tree saves up to be used to break dormancy or fight against severe stress (Richardson et al., 2013; Trumbore et al., 2015; Muhr et al., 2016). Therefore, when dealing with plant parts and remains it is also recommended to chemically isolate the fraction of carbon for ${ }^{14} \mathrm{C}$ dating. For ${ }^{14} \mathrm{C}$ tree ring studies, for instance, "cellulose" - also termed alpha-cellulose (Leavitt and Bannister, 2009), or hollocelulose extract (Southon and Magana, 2010; Santos et al., 2015; Baker et al., 2017) - is the preferable structural component of plants to be used for ${ }^{14} \mathrm{C}$ dating.

Since the actual $\mathrm{C}$ concentration in plant organs is often high (30-40\% of the dry weight), its multiple carbon pools can be apportioned from a relatively small mass of "raw" material by standardized chemical protocols before isotopic analysis are undertaken. With regard to phytC, its very low concentration (e.g. 0.1-1\% dry weight; Smith and White, 2004) prevents any specific separation targeting atm- $\mathrm{CO}_{2}$ molecular byproducts and/or the removal of embedded solute compounds of soil-C origin, among others. Moreover, to produce a sample for ${ }^{14} \mathrm{C}$ dating, a significant pool of phytoliths (and consequently plant remains) is required, thus increasing the chances of any soil- $C$ contributions within the existing plant tissue pool builds up. Therefore, it is not surprising that chemical phytolith extraction procedures that do not successfully remove external organic residues will also show large ${ }^{14} \mathrm{C}$ offsets, occasionally amplified towards thousand years old (Table 1).

In contrast to what has been detected in phytC ${ }^{14} \mathrm{C}$, there were no detectable biases resulting from old soil- $\mathrm{C}$ contributions to plant-C ${ }^{14} \mathrm{C}$ results. This implies the existence of a process that translocates old soil-C mobilized by the roots directly to phytoliths. As previously discussed in Reyerson et al. (2016), further studies are needed to investigate whether dissolution of soil silicon-organic compounds during active uptake of silicon by plants (Ma et al., 2006) may allow soil-C to be chelated with Si, absorbed by the roots, and concentrated in phytoliths (Alexandre et al., 2016).

\subsection{Understanding plant cell silicification, cavity formation and carbon occlusions}

Plant cells display some highly complex and unique functions that are too complex to be discussed in depth here. However, prior research has shown that Si, N, C (as gas or solute by-products), among other elements, can be transported and exchanged within the plant cell and between adjacent cells. Of these, our focus will be on $\mathrm{Si}$ and protein transport, $\mathrm{C}$ entrapment in phytoliths, and cavity formation.

Silicon translocation processes in plant parts have been mapped in association to aquaporin-like proteins (Ma et al., 2006, 2007, 2011; Yamaji et al., 2008, 2012; Ma and Yamaji, 2015). Aquaporins are responsible for several transcellular functions, including nutrient acquisition and silicon transport from soils to roots, shoots and ultimately to leaf blades and sheaths. Aquaporins can be found in the plasma membrane and subcellular sections, and therefore are responsible for the translocation of solutes and gases between intracellular compartments and the cell surface (Maurel et al., 2009; Luu and Maurel, 2013; Hachez et al., 2013). They are also linked to $\mathrm{C}$ and $\mathrm{N}$ fixation, including those from soil solutes as suggested by Pinton et al. (2016).

Since cell signaling is vital to plants as a way to respond to changes in their environment, plant cells must be able to communicate with each other as well (Maurel et al., 2015, Zhalnina et al., 2018 for example). Plasmodesmata are intercellular junction cells that enable such communications, the movement of selected inorganic ions and other molecules between adjacent viable cells. Silicifying silica cells still maintain their cytoplasmic connection to neighboring cells through plasmodesmata as the viable silica cell deposits silica (Kumar et al., 2017). This interconnection allows - to some extent - the exportation and remobilization of internal nutrients (organic nutrition transported with the help of aquaporins), before silicification reaches "maturation" (Schopf, 1975, Lawton, 1980). Through comprehensive analysis involving dye and confocal images, researchers showed that silicified cells do not trap the nuclei but can include small vacuoles, which are considerably diminished in size once the process is complete (Kumar et al., 2017). Shrunken cytoplasm in partially silicified cells was also observed in a much larger inner volume. Moreover, not all cells programed to undergo silica deposition are fully silicified, as cell death can occur at any stage of the silicification process (Kumar and Elbaum, 2017). These findings support the observations of phytolith inner voids and large empty cavities (Alexandre et al., 2015) that are commonly mistaken by the dark or opaque spots visible on optical-microscopy examination. In this respect, phytolith voids are not a product of harsh extractions, as it has been advocated by Sullivan and Parr (2013) and echoed by others (Asscher et al., 2017 and references there in). Given this orientation, further observations may be made. First, the interconnection between actively silicifying cells and viable cells, and the visual observations of reduction of inner cell products (Kumar et al., 2017; Kumar and Elbaum, 2017) would be consistent with lower phytC content occlusions (e.g. $0.1-1 \%$ dry weight; Smith and White, 2004). Therefore, inflated phytC\% values reported in the literature in association with soil accumulation of phytoliths (Santos and Alexandre, 2017), and/or suspiciously large graphite targets produced from lesser phytolith amounts for ${ }^{14} \mathrm{C}$ AMS are most likely a product of organic residue contamination (pre- or post-burial). This interpretation reinforces the need of robust screening methods to evaluate phytolith extraction purity before isotopic analysis take place, such as SEM-EDX (Corbineau et al., 2013). Second, organic direct induction of silica has been duplicated in vitro (Law and Exley, 2011) as well as in plant tissue (Brugiére and Exley, 2017). Thus, the movement of $\mathrm{C}$ and $\mathrm{N}$ in plant cells, including those originally from soil nutrient solutes, has also been well evidenced as discussed above. Therefore, these issues can no longer be ignored when studying phytoliths for isotopic analysis.

\subsection{Lack of mechanistic understanding and its implications to phytC ${ }^{14} \mathrm{C}$ dating}

As mentioned earlier, there are few cases where phytC ${ }^{14} \mathrm{C}$ signatures and/or ages in living plant appear to be reasonable. This is for instance the case of the phytolith sample extracted using a somewhat "gentler" protocol presented in Fig. 3 (top panel) as Ambient 1a-LacCore. Although to be clear, our gentler protocol was designed to produce pure extracts, as has been shown by SEM-EDX (Fig. S1 and S2 in Reyerson et al., 2016 Supplement). Sample Ambient 1a-LacCore yielded the closest ${ }^{14} \mathrm{C}$ signature compared to that of the host-plant. However, in another sample (FACE 1a-LacCore, Fig. 3, bottom panel), the use of the same protocol led to a phytC ${ }^{14} \mathrm{C}$ signature different from the value expected, demonstrating the $C$ continuum encapsulated in phytoliths plays by far a more important role than the choice of protocol or its degree of oxidation. This fact was sufficiently accounted for when a subset of samples was subjected to the same protocol as a group (Fig. 4), and yet phytC ${ }^{14} \mathrm{C}$ values still vary by almost \pm 700 yrs BP. This is in disagreement with recent studies (Piperno, 2016a; Asscher et al., 2017), suggesting that the use of protocols with "lesser oxidizing strength" would allow phytoliths to be used for ${ }^{14} \mathrm{C}$ age determinations. However, an in depth discussion of complex carbon pools coupled with their susceptibility to oxidation have not been taken into consideration in those studies.

To illustrate that chemical over-oxidation alone is unlikely to 


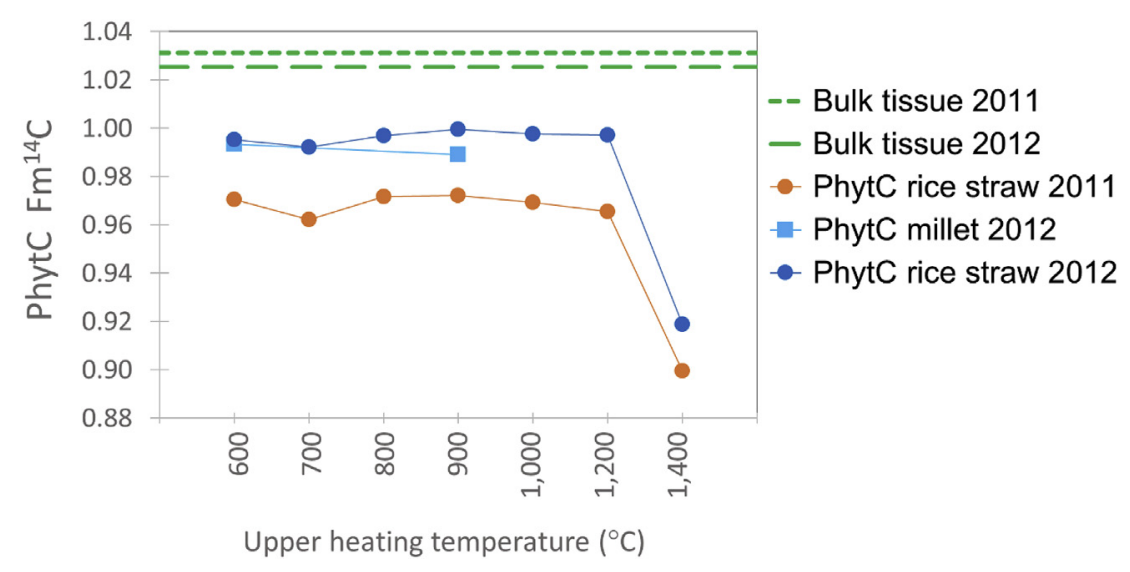

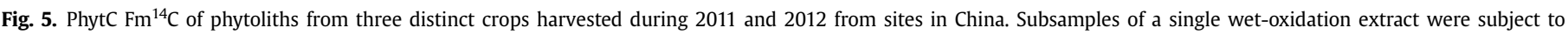

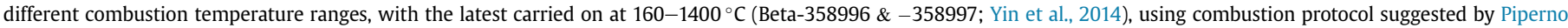

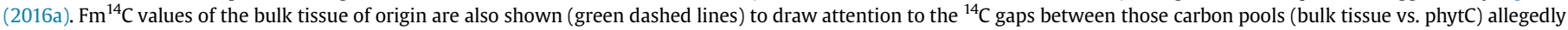

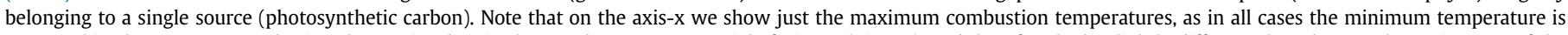

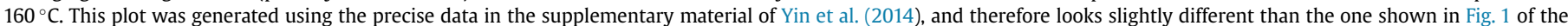
same article. (For interpretation of the references to color in this figure legend, the reader is referred to the Web version of this article.)

play any role in governing phytC ${ }^{14} \mathrm{C}$ offsets we plot in Fig. 5 the phytC ${ }^{14} \mathrm{C}$ results of modern crop phytoliths exposed to a multi-step thermal combustion procedure (Yin et al., 2014). Phytolith extracts produced by a single chemical protocol were subjected to distinct combustion ranges running from $600^{\circ} \mathrm{C}$ to $1400^{\circ} \mathrm{C}$ (Fig. 5). Since samples were flame-sealed in combustion tubes, after loaded and evacuated, the phytC ${ }^{14} \mathrm{C}$ differences can only be attributed to thermal apportionment of the total carbon pool within the concealed vessel at different temperature ranges. In this context, it is worthwhile to stress that both phytC fractions, atm- $\mathrm{CO}_{2}$ and soil-C, are confined within the combustion vessel and its associated $\mathrm{CO}_{2}$ evolved was released as combustion temperature increased from $160^{\circ} \mathrm{C}$ to the upper heating temperature desired (as shown on the axis- $\mathrm{x}$ ).

The difference between the average ${ }^{14} \mathrm{C}$ values of the bulk rice straw and millet harvested in 2011-2012 (dashed lines in Fig. 5) is due to the year-to-year atm- ${ }^{14} \mathrm{CO}_{2}$ decrease of approximately $0.6 \%$ due to global fossil fuel emissions (Graven, 2015). Yin et al. (2014) stated that the majority of phytC $\mathrm{CO}_{2}$ production occurred in two temperature ranges, $500-600^{\circ} \mathrm{C}$ and $800-900^{\circ} \mathrm{C}$. This assessment is in agreement with our findings of the phytC thermal decomposability pattern mentioned earlier and shown in Fig. 6 of Reyerson et al. (2016). Such a pattern can only be interpreted in terms of complex carbon pools that are more or less recalcitrant to oxidation. Still, if all fractions were from a single source (i.e. dominated by a photosynthetic signal), the ${ }^{14} \mathrm{C}$ ages should match those of the bulk plant-host and overlap between fractions (or temperature ranges). Nevertheless, all phytC ${ }^{14} \mathrm{C}$ results showed a significant mismatch compared to the straw and leaves of origin. The largest ${ }^{14} \mathrm{C}$ offset occurred for the full combustion range, at the upper temperature of $1400^{\circ} \mathrm{C}$. Moreover, the phytC ${ }^{14} \mathrm{C}$ offset from the rice straw of 2011 was much larger than that of 2012, illustrating that a systematic correction is impractical. Most importantly, since the concealed $\mathrm{CO}_{2}$ evolved could not be spoiled, those phytC ${ }^{14} \mathrm{C}$ results clearly indicated the presence of a secondary source to phytC. Finally, the discrepancies in the phytC $\mathrm{Fm}^{14} \mathrm{C}$ results shown in Fig. 5 were similar in magnitude to those reported by others (Sullivan and Parr, 2013; Piperno, 2016a).

Recent ${ }^{14} \mathrm{C}$ dating of phytC in archaeological contexts (e.g. Asscher et al., 2017; Zuo et al., 2016, 2017) should be carefully considered. Asscher et al. (2017) described a new method to extract carbon from phytolith rich layers to undergo ${ }^{14} \mathrm{C}$ age determinations. The method relies on properly recovering and dating a $40 \%$ insoluble carbon fraction obtained from pure phytoliths. After these steps are accomplished, results "could be used for high resolution chronological questions". Note that phrase between quotations in this paragraph are the author's words. We are unable to reproduce the $40 \%$ insoluble carbon fraction claimed in Asscher et al. (2017), and are puzzled as to how they define and/or attained this \%C. However, if a $40 \%$ insoluble carbon fraction was obtained from just $50 \mathrm{mg}$ of purified phytoliths as stated in Asscher et al. (2017), sample RTD-7262 in Fig. 2 protocol 1, it would imply that the total phytC was higher than $2 \%$ dry weight. This value would be 2 to 20 times higher than the values obtained using a chemical method verified to be $100 \%$ efficient for removing extraneous organic particles (from 0.1 to $1 \%$ dry weight; Smith and White, 2004, Corbineau et al., 2013). Thus, we suspect that a large portion of the carbon dated by Asscher et al. (2017) is carbon impurities, e.g. an artifact from the presence of post-burial carbon within the unsealed elongated voids detected during the microCT analysis as stated in the paper. It was assumed that this external carbon could be removed by acid and alkaline treatments before and after phytolith dissolution, respectively. In the most immediate sense, that means accepting without independent prove that the post-burial nano or micro charred carbon that permeate those layers and can potentially be transferred into the unsealed voids is completely soluble. Solid evidence to support this line of reasoning should had been presented, especially when the carbon from the well-dated layers found above and below the phytolith-rich layer was used as age reference. Regarding the mature common wheat plant-phytolith pair tested (Table 2 of Asscher et al., 2017), dryashing was used to remove plant tissue and isolate pure phytoliths. Although extracts were also screened for impurities, prior to dissolution, it is stated that "samples that contained char plant materials were examined under a binocular [microscope] and the larger char particles were removed with tweezers prior to dissolution of phytoliths." Nano and micro biochar particles would be difficult to spot and absolutely impossible to remove manually. They would not necessarily produce agreements between the ${ }^{14} \mathrm{C}$ results of phytoliths and the host-plant, if inputs of soil-C to rootplant (and phytC) are significant, but they can augment the phytC \%. Indeed, from their phytC ${ }^{14} \mathrm{C}$ plant-phytolith pair results, Asscher et al. (2017) found a 'too-old' phytC ${ }^{14} \mathrm{C}$ effect, and even estimated it as $~ 7 \%$. Moreover, large phytC\% is in disagreement with direct 
Table 2

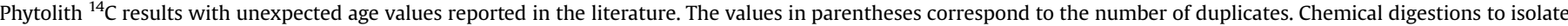

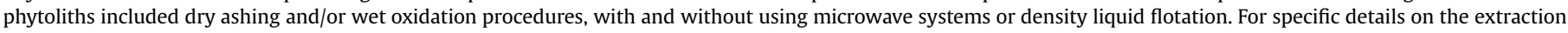
protocols, refer to the original publication.

\begin{tabular}{|c|c|c|c|c|}
\hline \multicolumn{2}{|c|}{ Host material and location } & \multirow{2}{*}{$\begin{array}{l}\text { Range of }{ }^{14} \mathrm{C} \\
\text { age anomalies } \\
\sim 2-8 \text { kyrs }(5)\end{array}$} & \multirow{2}{*}{$\begin{array}{l}\text { AMS Facility } \\
\text { KCCAMS/UCI }\end{array}$} & \multirow{2}{*}{$\begin{array}{l}\text { Cited in } \\
\text { Santos et al., 2010a, 2012b }\end{array}$} \\
\hline Living vegetation & Grasses harvested before 2010, France and USA & & & \\
\hline & Bamboo leaves harvested before 2008 and litter, Australia & 400 to 3510 yrs (12) & ANSTO & $\begin{array}{l}\text { Sullivan and Parr 2013, } \\
\text { Santos et al., } 2012 \mathrm{a}^{\mathrm{b}}\end{array}$ \\
\hline & Rice \& millet harvested in 2011 and 2012, China & $>2$ kyrs $(16)$ & $\begin{array}{l}\text { Peking University \& } \\
\text { Beta Analytic, Inc. }\end{array}$ & Yin et al., 2014 \\
\hline & Sorghum harvested in 1999, USA, and wheat harvested in 2012, Italy & Bomb to 3kyrs (57) & KCCAMS/UCI & Reyerson et al., 2016 \\
\hline & $\begin{array}{l}\text { Several plants from different years between } 1964 \text { and 2013, } \\
\text { Panama and Ecuador }\end{array}$ & Bomb to $\sim 4$ kyrs $(8)$ & Beta Analytic, Inc. & $\begin{array}{l}\text { Piperno, 2016a , } \\
\text { Santos et al., } 2016 \text { b }\end{array}$ \\
\hline & Hard beech harvested before 2007, New Zealand & $>2$ kyrs (1) & Rafter Radiocarbon & Santos et al., 2016 \\
\hline \multirow[t]{8}{*}{ Fossil } & Soil, USA & $\sim 10 \mathrm{kyrs}(1)$ & Isotopes, Inc. & Wilding 1967 \\
\hline & Soils, USA & Age inversions (6) & NSF-Arizona & Kelly et al., 1991 \\
\hline & Soils, USA & 800 to 8 kyrs (6) & NSF-Arizona & McClaran and Umlauf 2000 \\
\hline & Sediments, New Zealand & $7-10$ kyrs (3) & Rafter Radiocarbon & $\begin{array}{l}\text { Rieser et al., } 2007 \text { (abstract), } \\
\text { dataset in Santos et al. (2016) }\end{array}$ \\
\hline & Topsoil layer, Cameroon & $\sim 1.5$ kyrs (10) & KCCAMS/UCI & Santos et al., 2010a \\
\hline & Topsoil layer, Senegal & $\sim 3$ kyrs (1) & KCCAMS/UCI & Santos et al., 2016 \\
\hline & Soils, China & $1 \mathrm{kyr}(1)$ & Beta Analytic, Inc. & Zuo et al., 2016 \\
\hline & Sediments, Israel & 200 to 1300 yrs (5) & Dangoor Research AMS & Asscher et al. (2017) \\
\hline
\end{tabular}

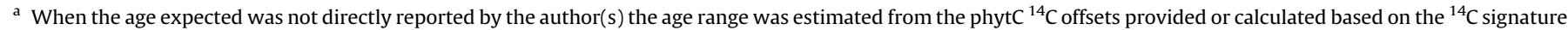
of the harvested year.

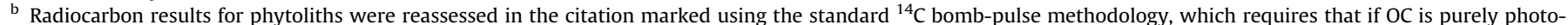
synthetic its ${ }^{14} \mathrm{C}$ value should match the year or period of harvesting.

observations in living vegetation during silicification. Recent research work have showed that during Si-cell maturation, cell contents tend to decrease (Kumar et al., 2017; Kumar and Elbaum, 2017). The phenomenon can be attributed to cell-to-cell communications during the silicification process and the movement of nutrients out of the cell before they can be completely encapsulated. This explanation has already asserted for the large empty cavities found in fresh and fossil phytoliths (Alexandre et al., 2015). But most importantly, it does illustrate that carbon occluded in phytoliths should be rather small.

Another recent dataset (Zuo et al., 2016, 2017) showed reasonable matches between calibrated ${ }^{14} \mathrm{C}$ ages of phytolith extracts, whose purity has been tested by SEM-EDX, and chars and plant remains from unaltered archaeological levels. The protocol used on both set of samples was the same in terms of chemicals, strength and duration. For an average phytc\% lower and tighter, e.g. $0.12 \pm 0.05 \%(n=9)$, the phytC ${ }^{14} \mathrm{C}$ ages produced were in better agreement with the age distribution using other carbonaceous materials (Zuo et al., 2017). However, when the average phytC\% was more variable, e.g. $0.59 \pm 0.47 \%(n=7)$, the phytC ${ }^{14} \mathrm{C}$ ages of over $40 \%$ of the data were scattered by $\pm 200-300$ years when compared with other organics in the same layers (Zuo et al., 2016). In addition, one sample yielded an odd age (e.g. 1 kyrs too old), and therefore was deemed as an outlier. Authors explained that discrepancies must be due to vertical translocation of the phytolith composition within the sequence, a common phenomenon when dealing with fossil phytoliths. While it is known that phytoliths can move upward as well as downward (Alexandre et al., 1997, 2011; BasileDoelsch et al., 2005; Fishkis et al., 2010) due to different factors, the point is that if the archaeological age-depth material is not reliable, the ability to validate the phytolith dating hypothesis is automatically compromised. Moreover, remobilization should be another concern to be considered when singling materials for age determinations, especially in archaeological contexts. Age determinations based on remobilization would always be open to subjective interpretation.

Although phytC ${ }^{14} \mathrm{C}$ age anomalies are now widespread, the irrelevance of using phytC as reliable dating tool or proxy for atm-
$\mathrm{CO}_{2}$ has been denied (e.g. Piperno, 2016b). Some studies suggested that the phytC ${ }^{14} \mathrm{C}$ age anomalies must be associated with the chemical extractions applied or unverified phenomena (isotopicfractionation, or even pollution by chemicals - references in Santos and Alexandre, 2017). All of those, however, have been addressed in our data and research summarized above. Most importantly, inconsistencies in living plant phytC ${ }^{14} \mathrm{C}$ results against expected values occurred in over 95\% of the cases (Santos et al., 2010a; Sullivan and Parr, 2013; Yin et al., 2014; Piperno, 2016a; Asscher et al., 2017). These inconsistencies were independent of phytolith extraction protocol (ashing and/or wet oxidation with or without alkaline etching, or microwave-assisted digestion). Our contention is that living plant phytC ${ }^{14} \mathrm{C}$ offsets occurred within a method and/ or among methods, and apart of oxidation strength and duration. Thus, the phytC ${ }^{14} \mathrm{C}$ dating results from these experiments confounded the assumption that phytC is a reliable proxy of plant $\mathrm{C}$ and of atm- $-\mathrm{CO}_{2}$. This should be of great concern, as measurements were performed to validate phytC as a proxy of atm- $\mathrm{CO}_{2}$, rather than to obtain an age assessment (calendar age of plant material was known). A compilation of phytC ${ }^{14} \mathrm{C}$ age anomalies (or unexpected too old results) is provided in Table 2 . This compilation is likely incomplete, as failed attempts to use phytC ${ }^{14} \mathrm{C}$ age may have been unpublished. Nevertheless, we hope this paper will stimulate a re-evaluation of such data.

While the possibility remains that some phytC ${ }^{14} \mathrm{C}$ results match expected values, the impossibility of a priori estimating either the amplitude of the soil-C contribution to phytC or the mean ${ }^{14} \mathrm{C}$ age of the occluded soil- $C$ prevents the use of phyt $C$ as a reliable material for ${ }^{14} \mathrm{C}$ age determinations. Mixed pools of carbon, by their nature, detract from the reproducibility and accuracy necessary to determine ages.

\section{Summary}

PhytC has been assumed to be solely photosynthetic in origin, and therefore offered as an appropriate material for ${ }^{14} \mathrm{C}$ dating in archaeology and paleoenvironmental studies. However, applications of phytC ${ }^{14} \mathrm{C}$ dating, which are mostly based on straight- 
forward empirical evaluations of fossil phytolith extracts and other organics found in the same layers, have frequently yielded puzzling results. PhytC ${ }^{14} \mathrm{C}$ offsets in the range of hundreds to thousands of years have been obtained, calling for a thoroughgoing evaluation of phytolith extraction protocols, extract purity, and especially a careful investigation of the origin of phytC.

The soil- $C$ contribution to phytC has been unambiguously demonstrated by more than 200 comparative isotopic measurements $\left({ }^{14} \mathrm{C}\right.$ and $\left.\delta^{13} \mathrm{C}\right)$ of phytC, plant tissues, atmospheric $\mathrm{CO}_{2}$, and soil organic carbon samples (Reyerson et al., 2016), as well as $\mathrm{a}^{13} \mathrm{C}-{ }^{15} \mathrm{~N}$ amino acid labeled experiment (Alexandre et al., 2016). Other lines of investigation based on 3D-X Ray microscopy, NanoSIMS (Alexandre et al., 2015), SRS (Gallagher et al., 2015), DNP-NMR (Masion et al., 2017), have given insight into phytC location, molecular composition and accessibility to oxidation. These results have highlighted the need for the purity of the final phytolith extracts to be cross-checked by robust methods, such as SEM-EDX before being analyzed (Corbineau et al., 2013). Extracts that appear to be impure or based on $C$ inclusions post-burial, should not be classified as phytC per se.

In sum, a complete suite of findings supports a robust soil-C contribution to phytC, and gives us insight into its true nature. PhytC is a mixed pool of $\mathrm{C}$ composed of atm- $\mathrm{CO}_{2}$ and soil-C. Since soil- $C$ contains a heterogeneous mixture of various organic compounds with unequal distributions of labile and recalcitrant fractions, the chemical isolation of those fractions can yield distinct ${ }^{14} \mathrm{C}$ signatures/ages. The final effect on phytC ${ }^{14} \mathrm{C}$ age is therefore unpredictable. Since identifying scenarios in which phytC isotopic analysis may be appropriate is difficult (e.g. when soil-C to phytC is minimal and/or indistinguishable in ${ }^{14} \mathrm{C}$ from its host), we cannot confidently recommend its use for the purpose of determining absolute ages. When there is an insufficient amount of suitable carbonaceous material for dating, phytoliths alone should not be considered as an acceptable substitute. In order to constrain the possibility of an offset in phytolith age, a prediction of ages based on age-depth modelling, and/or other chronological controls (if available) must be considered. Moreover, all phytC ${ }^{14} \mathrm{C}$ ages obtained must be interpreted with extreme caution, due to their inherent limitations in accurately reproducing in vivo plant $\mathrm{C}$ signatures.

Although further studies are needed to better understand the underlying mechanisms that connect sources of $\mathrm{C}, \mathrm{Si}$ and other minerals at the molecular/genetic level, it has become increasingly clear that Si and the various mechanisms for solute-cell transport are very complex, and possibly involve equally intricate processes in silicifying plant cells. Originally, the key question driving this research was to determine the source of the $C$ in phytoliths. However, the synchronization of multiple lines of analytical evidence summarized here helped us to greatly advance our understanding of the origins of phytolith carbon. Nonetheless, quantification of the soil-C to phytC contribution is still needed for a better understanding of phytC conservation in soils and sediments as well as the phytC contribution to the carbon cycle at the soil-plant-atmosphere interface.

\section{Authors' contribution statement}

GMS took the lead in writing the manuscript. All authors provided critical feedback and helped shape the figures, tables and manuscript writing. All authors approved the final version.

\section{Acknowledgments}

Here we synthesized the results of recent experimental research supported by the Keck-Carbon Cycle AMS Facility at University of
California Irvine, the US National Science Foundation (DEB1144888), OSU-Institut Pythéas (Aix-Marseille Université-CNRSIRD), the French FIR 2010 (Aix-Marseille Université), ECCOREV 2011, AIR Archéométrie 2011(CNRS) and Labex OT-Med 2013. We thank Prof. Erv Taylor for the manuscript proof reading. The authors also wish to extend their thanks to the Editor Ana Moreno and the anonymous reviewers for their constructive comments.

\section{Appendix A. Supplementary data}

Supplementary data related to this article can be found at https://doi.org/10.1016/j.quascirev.2018.08.007.

\section{References}

Alagić, S.Č., Jovanović, V.P.S., Mitić, V.D., Cvetković, J.S., Petrović, G.M. Stojanović, G.S., 2016. Bioaccumulation of HMW PAHs in the roots of wild blackberry from the Bor region (Serbia): phytoremediation and biomonitoring aspects. Sci. Total Environ. 562, 561-570.

Alexandre, A., Colin, F., Meunier, J.-D., 1994. Phytoliths as Indicators of the Biogeochemical Turnover of Silicon in Equatorial forest, 319. Compte-rendus de l'Académie des Sciences, Paris, pp. 453-458.

Alexandre, A., Meunier, J.D., Colin, F., Koud, J.M., 1997. Plant impact on the biogeochemical cycle of silicon and related weathering processes. Geochem. Cosmochim. Acta 61 (3), 677-682.

Alexandre, A., Meunier, J.-D., Mariotti, A., Soubies, F., 1999. Late Holocene phytolith and carbon-isotope record from a latosol at salitre, south-Central Brazil. Quat. Res. 51, 187-194.

Alexandre, A., Bouvet, M., Abbadie, L., 2011. The role of savannas in the terrestrial Si cycle: a case-study from Lamto, Ivory Coast. Global Planet. Change 78 (3), $162-169$.

Alexandre, A., Basile-Doelsch, I., Delhaye, T., Borshneck, D., Mazur, J.C., Reyerson, P., Santos, G.M., 2015. New highlights of phytolith structure and occluded carbon location: 3-D X-ray microscopy and NanoSIMS results. Biogeosciences 12 $863-873$.

Alexandre, A., Balesdent, J., Cazevieille, P., Chevassus-Rosset, C., Signoret, P., Mazur, J.C., Harutyunyan, A., Doelsch, E., Basile-Doelsch, I., Miche, H., Santos, G. 2016. Direct uptake of organically derived carbon by grass roots and allocation in leaves and phytoliths: 13 C labeling evidence. Biogeosciences 13,1693-1703.

Asscher, Y., Weiner, S., Boaretto, E., 2017. A new method for extracting the insoluble occluded carbon in archaeological and modern phytoliths: detection of $14 \mathrm{C}$ depleted carbon fraction and implications for radiocarbon dating. J. Archaeol. Sci. 78, 57-65.

Baker, J.C., Santos, G.M., Gloor, M., Brienen, R.J., 2017. Does Cedrela always form annual rings? Testing ring periodicity across South America using radiocarbon dating. Trees (Berl.) 1-11.

Basile-Doelsch, I., Amundson, R., Stone, W.E.E., Masiello, C.A., Bottero, J.Y., Colin, F., Masin, F., Borschneck, D., Meunier, J.D., 2005. Mineralogical control of organic carbon dynamics in a volcanic ash soil on La Réunion. Eur. J. Soil Sci. 56 (6), 689-703.

Borrelli, N., Alvarez, M.F., Osterrieth, M.L., Marcovecchio, J.E., 2010. Silica content in soil solution and its relation with phytolith weathering and silica biogeochemical cycle in Typical Argiudolls of the Pampean Plain, Argentina-a preliminary study. J. Soils Sediments 10 (6), 983-994.

Bouchereau, A., Guéno, P., Larher, F., 2000. Analysis of amines in plant materials J. Chromatogr. B Biomed. Sci. Appl. 747 (1), 49-67.

Brugiére, T., Exley, C., 2017. Callose-associated silica deposition in Arabidopsis. J. Trace Elem. Med. Biol. 39, 86-90. https://doi.org/10.1016/j.jtemb.2016.08.005.

Cabanes, D., Weiner, S., Shahack-Gross, R., 2011. Stability of phytoliths in the archaeological record: a dissolution study of modern and fossil phytoliths. J. Archaeol. Sci. 38, 2480-2490.

Cain, W.F., Suess, H.E., 1976. Carbon 14 in tree rings. J. Geophys. Res. 81 (21), 3688-3694.

Carrasco, J.J., Neff, J.C., Harden, J.W., 2006. Modeling physical and biogeochemical controls over carbon accumulation in a boreal forest soil. J. Geophys. Res.: Biogeosciences 111 (G2).

Carter, J.A., 2009. Atmospheric carbon isotope signatures in phytolith-occluded carbon. Quat. Int. 193 (1), 20-29.

Corbineau, R., Reyerson, P.E., Alexandre, A., Santos, G.M., 2013. Towards producing pure phytolith concentrates from plants that are suitable for carbon isotopic analysis. Rev. Palaeobot. Palynol. 197, 179-185.

Cornelis, J.T., Dumon, M., Tolossa, A.R., Delvaux, B., Deckers, J., Van Ranst, E., 2014 The effect of pedological conditions on the sources and sinks of silicon in the Vertic Planosols in south-western Ethiopia. Catena 112, 131-138.

Dezzeo, N., Worbes, M., Ishii, I., Herrera, R., 2003. Annual tree rings revealed by radiocarbon dating in seasonally flooded forest of the Mapire River, a tributary of the lower Orinoco River, Venezuela. Plant Ecol. 168 (1), 165-175.

Exley, C., 2015. A possible mechanism of biological silicification in plants. Front. Plant Sci. 6, 853.

Fishkis, O., Ingwersen, J., Lamers, M., Denysenko, D., Streck, T., 2010. Phytolith 
transport in soil: a field study using fluorescent labelling. Geoderma 157 (1-2), 27-36.

Gallagher, K.L., Alfonso-Garcia, A., Sanchez, J., Potma, E.O., Santos, G.M., 2015. Plant growth conditions alter phytolith carbon. Front. Plant Sci. 6.

Gao, Y., Zhu, L., 2004. Plant uptake, accumulation and translocation of phenanthrene and pyrene in soils. Chemosphere 55, 1169-1178.

Gao, Y., Li, Q., Ling, W., Zhu, X., 2011. Arbuscular mycorrhizal phytoremediation of soils contaminated with phenanthrene and pyrene. J. Hazard Mater. 185, 703-709.

Gao, Y., Zhang, Y., Liu, J., Kong, H., 2013. Metabolism and subcellular distribution of anthracene in tall fescue (Festuca arundinacea Schreb.). Plant Soil 365, 171-182.

Gao, G., Jie, D., Wang, Y., Liu, L., Liu, H., Li, D., Li, N., Shi, J., Leng, C., 2018. Do soil phytoliths accurately represent plant communities in a temperate region? A case study of Northeast China. Veg. Hist. Archaeobotany 1-13. https://doi.org/ 10.1007/s00334-018-0670-2.

Gioseffi, E., de Neergaard, A., Schjoerring, J.K., 2012. Interactions between uptake of amino acids and inorganic nitrogen in wheat plants. Biogeosciences 9, 1509-1518.

Graven, H.D., 2015. Impact of fossil fuel emissions on atmospheric radiocarbon and various applications of radiocarbon over this century. Proc. Natl. Acad. Sci. Unit. States Am. 112, 9542-9545.

Hachez, C., Besserer, A., Chevalier, A.S., Chaumont, F., 2013. Insights into plant plasma membrane aquaporin trafficking. Trends Plant Sci. 18, 344-352. https:// doi.org/10.1016/j.tplants.2012.12.003.

Hansen, J., Sato, M., 2016. Regional climate change and national responsibilities. Environ. Res. Lett. 11 (3) p.034009.

Harvey, O.R., Kuo, L.J., Zimmerman, A.R., Louchouarn, P., Amonette, J.E., Herbert, B.E. 2012. An index-based approach to assessing recalcitrance and soil carbon sequestration potential of engineered black carbons (biochars). Environ. Sci. Technol. 46, 1415-1421.

Hebert, G.N., Odom, M.A., Bowman, S.C., Strauss, S.H., 2004. Attenuated total reflectance FTIR detection and quantification of low concentrations of aqueous polyatomic anions. Anal. Chem. 76, 781-787.

Hildebrandt, T.M., Nesi, A.N., Araújo, W.L., Braun, H.P., 2015. Amino acid catabolism in plants. Mol. Plant 8 (11), 1563-1579.

Hodson, M.J., Parker, A.G., Leng, M.J., Sloane, H.J., 2008. Silicon, oxygen and carbon isotope composition of wheat (Triticum aestivum L.) phytoliths: implications for palaeoecology and archaeology. J. Quat. Sci. 23, 331-339. ISSN 0267-8179.

Hua, Q., Barbetti, M., Rakowski, A.Z., 2013. Atmospheric radiocarbon for the period 1950-2010. Radiocarbon 55 (4), 2059-2072.

Jajoo, A., 2017. Effects of environmental pollutants polycyclic aromatic hydrocarbons (PAH) on photosynthetic processes. In: Photosynthesis: Structures, Mechanisms, and Applications. Springer International Publishing, pp. 249-259.

Jones, D.L., Nguyen, C., Finlay, R.D., 2009. Carbon flow in the rhizosphere: carbon trading at the soil-root interface. Plant Soil 321, 5. https://doi.org/10.1007/ s11104-009-9925-0.

Kelly, E.F., Amundson, R.G., Marino, B.D., Deniro, M.J., 1991. Stable isotope ratios of carbon in phytoliths as a quantitative method of monitoring vegetation and climate change. Quat. Res. 35, 222-233.

Klein, T., Siegwolf, R.T., Körner, C., 2016. Belowground carbon trade among tall trees in a temperate forest. Science 352 (6283), 342-344.

Kumar, S., Elbaum, R., 2017. Interplay between silica deposition and viability during the life span of sorghum silica cells. New Phytol. https://doi.org/10.1111/ nph.14867.

Kumar, S., Milstein, Y., Brami, Y., Elbaum, M., Elbaum, R., 2017. Mechanism of silica deposition in sorghum silica cells. New Phytol. 213 (2), 791-798.

Law, C., Exley, C., 2011. New insight into silica deposition in horsetail (Equisetum arvense). BMC Plant Biol. 11, 112. https://doi.org/10.1186/1471-2229-11-112.

Lawton, J.R., 1980. Observations on the structure of epidermal cells, particularly the cork and silica cells, from the flowering stem internode of Lolium temulentum L. (Gramineae). Bot. J. Linn. Soc. 80, 161-177.

Leavitt, S.W., Bannister, B., 2009. Dendrochronology and radiocarbon dating: the laboratory of tree-ring research connection. Radiocarbon 51 (1), 373-384.

Lin, S., Reppert, J., Hu, Q., Hudson, J.S., Reid, M.L., Ratnikova, T.A., Rao, A.M., Luo, H., Ke, P.C., 2009. Uptake, translocation, and transmission of carbon nanomaterials in rice plants. Small 5 (10), 1128-1132.

Lindon, J.C., Tranter, G.E., Koppenaal, D.W., 2016. In: Encyclopedia of Spectroscopy and Spectrometry, third ed. Academic Press. 3584pp, ISBN: 978-0-12-803224-4.

Liu, Q., Chen, B., Wang, Q., Shi, X., Xiao, Z., Lin, J., Fang, X., 2009. Carbon nanotubes as molecular transporters for walled plant cells. Nano Lett. 9 (3), 1007-1010.

Luu, D.T., Maurel, C., 2013. Aquaporin trafficking in plant cells: an emerging membrane-protein model. Traffic 14 (6), 629-635.

Ma, J.F., Yamaji, N., 2015. A cooperative system of silicon transport in plants. Trends Plant Sci. 20 (7), 435-442.

Ma, J.F., Tamai, K., Yamaji, N., Mitani, N., Konishi, S., Katsuhara, M., Ishiguro, M., Murata, Y., Yano, M., 2006. A silicon transporter in rice. Nature 440, 688-691.

Ma, J.F., Yamaji, N., Mitani, N., Tamai, K., Konishi, S., Fujiwara, T., Katsuhara, M., Yano, M., 2007. An efflux transporter of silicon in rice. Nature 448 (7150), 209-213.

Ma, J.F., Yamaji, N., Mitani-Ueno, N., 2011. Transport of silicon from roots to panicles in plants. Proc. Jpn. Acad. Ser. B Phys. Biol. Sci. 87, 377-385.

Masion, A., Alexandre, A., Ziarelli, F., Viel, S., Santos, G.M., 2017. Dynamic Nuclear Polarization NMR as a new tool to investigate the nature of organic compounds occluded in plant silica particles. Sci. Rep. 7.

Maurel, C., Santoni, V., Luu, D.T., Wudick, M.M., Verdoucq, L., 2009. The cellular dynamics of plant aquaporin expression and functions. Curr. Opin. Plant Biol. 12, 690-698. https://doi.org/10.1016/j.pbi.2009.09.002.

Maurel, C., Boursiac, Y., Luu, D.T., Santoni, V., Shahzad, Z., Verdoucq, L., 2015. Aquaporins in plants. Physiol. Rev. 95 (4), 1321-1358.

McClaran, M.P., Umlauf, M., 2000. Desert grassland dynamics estimated from carbon isotopes in grass phytoliths and soil organic matter. J. Veg. Sci. 11 (1), $71-76$.

Muhr, J., Messier, C., Delagrange, S., Trumbore, S., Xu, X., Hartmann, H., 2016. How fresh is maple syrup? Sugar maple trees mobilize carbon stored several years previously during early springtime sap-ascent. New Phytol. 209 (4), 1410-1416.

Näsholm, T., Kielland, K., Ganeteg, U., 2009. Uptake of organic nitrogen by plants. New Phytol. 182, 31-48. https://doi.org/10.1111/j.1469-8137.2008.02751.x.

Nogué, S., Whicher, K., Baker, A.G., Bhagwat, S.A., Willis, K.J., 2017. Phytolith analysis reveals the intensity of past land use change in the Western Ghats biodiversity hotspot. Quat. Int. 437, 82-89.

Oleschko, K., Parrot, J.F., Ronquillo, G., Shoba, S., Stoops, G., Marcelino, V., 2004. Weathering: toward a fractal quantifying. Math. Geol. 36, 607-628.

Opalinska, B., Cowling, S.A., 2015. Modelling the movement of biogenic silica from terrestrial vegetation to riverine systems within the continental USA. Ecol. Model. 312, 104-113.

Paungfoo-Lonhienne, C., Lonhienne, T.G.A., Rentsch, D., Robinson, N., Christie, M., Webb, R.I., Gamage, H.K., Carroll, B.J., Schenk, P.M., Schmidt, S., 2008. Plants can use protein as a nitrogen source without assistance from other organisms. Proc. Natl. Acad. Sci. 105, 4524-4529.

Paungfoo-Lonhienne, C., Rentsch, D., Robatzek, S., Webb, R.I., Sagulenko, E., Näsholm, T., Schmidt, S., Lonhienne, T.G., 2010. Turning the table: plants consume microbes as a source of nutrients. PLoS One 5 (7) p.e11915.

Paungfoo-Lonhienne, C., Visser, J., Lonhienne, T.G.A., Schmidt, S., 2012. Past, present and future of organic nutrients. Plant Soil 359, 1. https://doi.org/10.1007/ s11104-012-1357-6.

Petsch, S.T., Eglinton, T.I., Edwards, K.J., 2001. 14C-dead living biomass: evidence for microbial assimilation of ancient organic carbon during shale weathering. Science 292 (5519), 1127-1131.

Pinton, R., Tomasi, N., Zanin, L., 2016. Molecular and physiological interactions of urea and nitrate uptake in plants. Plant Signal. Behav. 11 (1) pp. e1076603.

Piperno, D.R., 2006. Phytoliths: a Comprehensive Guide for Archaeologists and Paleoecologists. AltaMira, Lanham, MD, 238pp.

Piperno, D.R., 2016b. Phytolith radiocarbon dating in archaeological and paleoecological research: a case study of phytoliths from modern Neotropical plants and a review of the previous dating evidence. J. Archaeol. Sci. https://doi.org/10. 1016/j.jas.2015.06.002.

Piperno, D.R., 2016b. Standard evaluations of bomb curves and age calibrations along with consideration of environmental and biological variability show the rigor of phytolith dates on modern neotropical plants: review of comment by Santos, Alexandre, and Prior. J. Archaeol. Sci. 71, 59-67.

Prior, C., Vandergoes, M., Howarth, J., 2011. Testing the effect of Sodium Polytungstate on pollen concentrate sample preparation procedures for AMS 14C dating. In: Abstract of a Poster Presented at the AMS-12 Conference, Wellington, New Zealand.

Rentsch, D., Schmidt, S., Tegeder, M., 2007. Transporters for uptake and allocation of organic nitrogen compounds in plants. FEBS Lett. 581 (12), 2281-2289.

Reyerson, P.E., Alexandre, A., Harutyunyan, A., Corbineau, R., Martinez De La Torre, H.A., Badeck, F.W., Cattivelli, L., Santos, G.M., 2016. Unambiguous evidence of old soil carbon in grass biosilica particles. Biogeosciences 13 (4), 1269-1286.

Richardson, A.D., Carbone, M.S., Keenan, T.F., Czimczik, C.I., Hollinger, D.Y., Murakami, P., Schaberg, P.G., Xu, X., 2013. Seasonal dynamics and age of stemwood nonstructural carbohydrates in temperate forest trees. New Phytol. 197 (3), 850-861.

Rieser, U., Carter, J.A., Prior, C.A., 2007. Phytoliths: a new chronometer for the late Quaternary. In: Abstract of a Poster Presented at the INQUA 2007 Conference, Cairns, Australia.

Santos, G.M., 2009. Comment on Atmospheric carbon isotope signatures in phytolith occluded carbon, Carter, JA, Quaternary International, this volume. Quat. Int. 193 (1), 30-31.

Santos, G.M., Alexandre, A., 2017. The phytolith carbon sequestration concept: fact or fiction? A comment on "Occurrence, turnover and carbon sequestration potential of phytoliths in terrestrial ecosystems by Song et al. Earth Sci. Rev. 164, 251. https://doi.org/10.1016/j. earscirev. 2016.04. 007".

Santos, G.M., Alexandre, A., Coe, H.H., Reyerson, P.E., Southon, J.R., De Carvalho, C.N., 2010a. The phytolith 14C puzzle: a tale of background determinations and accuracy tests. Radiocarbon 52, 113-128.

Santos, G.M., Southon, J.R., Drenzek, N.J., Ziolkowski, L.A., Druffel, E., Xu, X.M., Zhang, D., Trumbore, S., Eglinton, T.I., Hughen, K.A., 2010b. Blank assessment for ultra-small radiocarbon samples: chemical extraction and separation versus AMS. Radiocarbon 52 (3), 1322-1335.

Santos, G.M., Southon, J.R., Alexandre, A., Corbineau, R., Reyerson, P.E., 2012a. Interactive comment on "Comment on: "Possible source of ancient carbon in phytolith concentrates from harvested grasses" by G. M. Santos et al. (2012a)" by L. A. Sullivan and J. F. Parr. Biogeosci. Discuss. 9, C6114-C6124. www. biogeosciences-discuss.net/9/C6114/2012/bgd-9-C6114-2012.pdf.

Santos, G.M., Alexandre, A., Southon, J.R., Treseder, K.K., Corbineau, R., Reyerson, P.E., 2012b. Possible source of ancient carbon in phytolith concentrates from harvested grasses. Biogeosciences 9, 1873-1884.

Santos, G.M., Linares, R., Lisi, C.S., Tomazello Filho, M., 2015. Annual growth rings in 
a sample of Paraná pine (Araucaria angustifolia): toward improving the $14 \mathrm{C}$ calibration curve for the Southern Hemisphere. Quat. Geochronol. 25, 96-103.

Santos, G.M., Alexandre, A., Prior, C.A., 2016. From radiocarbon analysis to interpretation: a comment on "phytolith radiocarbon dating in archaeological and paleoecological research: a case study of phytoliths from modern neotropical plants and a review of the previous dating evidence", JAS (2015). doi: 10.1016/ j.jas.2015.06.002. by Dolores R. Piperno" J. Archaeol. Sci. 71, 51-58. https:// doi.org/10.1016/j.jas.2016.04.015.

Sauheitl, L., Glaser, B., Weigelt, A., 2009. Uptake of intact amino acids by plants depends on soil amino acid concentrations. Environ. Exp. Bot. 66, 145-152.

Schopf, J.M., 1975. Modes of fossil preservation. Rev. Palaeobot. Palynol. 20 (1-2), 27-53.

Sessa, C., Vila, A., García, J.F., 2011. Determination of detection limits for SEM-EDS and m-FTIR analysis of artwork. Anal. Bioanal. Chem. 400, 2241-2251.

Smith, F.A., White, J.W.C., 2004. Modern calibration of phytolith carbon isotope signatures for C3/C4 paleograssland reconstruction. Palaeogeogr. Palaeoclimatol. Palaeoecol. 207 (3-4), 277-304.

Southon, J.R., Magana, A.L., 2010. A comparison of cellulose extraction and ABA pretreatment methods for AMS 14 C dating of ancient wood. Radiocarbon 52 (3), 1371-1379.

Stemmet, M.C., De Bruyn, J.A., Zeeman, P.B., 1962. The uptake of carbon dioxide by plant roots. Plant Soil 17 (3), 357-364.

Sullivan, L.A., Parr, J.F., 2013. Comment on possible source of ancient carbon in phytolith concentrates from harvested grasses by GM Santos, et al. (2012). Biogeosciences 10 (2), 977-980.

Sullivan, L.A., Parr, J.F., Smith, A., Jakobsen, G., 2008. Bomb Pulse Dating of Phytolith Occluded Carbon for Quantification of Carbon Sequestration in Perennial Vegetation. Progress Report No. AINGRA08061. AINSE e Australian Institute of Nuclear Science and Engineering.

Tans, P.P., de Jong, A.F.M., Mook, W.G., 1978. Chemical pretreatment and radial flow of $14 \mathrm{C}$ in tree rings. Nature 271, 234-235.

Tripathi, S., Sonkar, S.K., Sarkar, S., 2011. Growth stimulation of gram (Cicer arietinum) plant by water soluble carbon nanotubes. Nanoscale 3 (3), 1176-1181.

Trumbore, S., Czimczik, C.I., Sierra, C.A., Muhr, J., Xu, X., 2015. Non-structural carbon dynamics and allocation relate to growth rate and leaf habit in California oaks. Tree Physiol. 35 (11), 1206-1222.

Vilgé-Ritter, A., 1997. PhD thesis. Etude des mécanismes d'élimination de la matière organique des eaux de surface par coagulation à l'aide de sels d'aluminium ou de fer, vol. 3. University of Aix Marseille, France, 299pp.

Voort, T.S.V.D., Hagedorn, F., McIntyre, C., Zell, C., Walthert, L., Schleppi, P., Feng, X., Eglinton, T.I., 2016. Variability in $14 \mathrm{C}$ contents of soil organic matter at the plot and regional scale across climatic and geologic gradients. Biogeosciences 13 (11), 3427-3439.

Voort, T.S.V.D., Zell, C.I., Hagedorn, F., Feng, X., McIntyre, C.P., Haghipour, N., Graf Pannatier, E., Eglinton, T.I., 2017. Diverse soil carbon dynamics expressed at the molecular level. Geophys. Res. Lett. 44 (23).

Warren, C.R., 2013. Quaternary ammonium compounds can be abundant in some soils and are taken up as intact molecules by plants. New Phytol. 198 (2), 476-485.

Watkinson, S.C., 2016. Physiology and Adaptation, Chapter 5, pp. 141-187. In: Watkinson, S.C., Boddy, L., Money, N.P. (Eds.), The Fungi, third ed. Academic Press, Elsevier, Waltham, San Diego, Oxford, London, p. 466. ISBN 978-0-12-
382034-1.

Watling, K.M., Parr, J.F., Rintoul, L., Brown, C.L., Sullivan, L.A., 2011. Raman, infrared and XPS study of bamboo phytoliths after chemical digestion. Spectrochim. Acta Part A Mol. Biomol. Spectros. 80, 106-111. https://doi.org/10.1016 j.saa.2011.03.002.

Webb, E., Longstaffe, F., 2010. Limitations on the climatic and ecological signals provided by the $\mathrm{d} 13 \mathrm{C}$ values of phytoliths from C4 North American praire grass. Geochem. Cosmochim. Acta 74, 3041-3050.

Weigelt, A., Bol, R., Bardgett, R.D., 2005. Preferential uptake of soil nitrogen forms by grassland plant species. Oecologia 142, 627. https://doi.org/10.1007/s00442004-1765-2.

White, A.F., Vivit, D.V., Schulz, M.S., Bullen, T.D., Evett, R.R., Aagarwal, J., 2012 Biogenic and pedogenic controls on $\mathrm{Si}$ distributions and cycling in grasslands of the Santa Cruz soil chronosequence, California. Geochem. Cosmochim. Acta 94 $72-94$.

Whiteside, M.D., Treseder, K.K., Atsatt, P.R., 2009. The brighter side of soils: quantum dots track organic nitrogen through fungi and plants. Ecology 90 (1), $100-108$.

Whiteside, M.D., Digman, M.A., Gratton, E., Treseder, K.K., 2012. Organic nitrogen uptake by arbuscular mycorrhizal fungi in a boreal forest. Soil Biol. Biochem. 55, 7-13.

Wilding, L.P. Radiocarbon dating of biogenetic opal. Science 156, 66-67.

Woodburn, T.L., Johnson, W.C., Mason, J.A., Bozarth, S.R., Halfen, A.F., 2017. Vegetation dynamics during the pleistocene-holocene transition in the central great Plains, USA. Holocene 27, 155-163.

Worbes, M., Junk, W.J., 1989. Source dating tropical trees by means of $14 \mathrm{C}$ from bomb tests. Ecology 70 (2), 503-507.

Yamaji, N., Mitatni, N., Ma, J.F., 2008. A transporter regulating silicon distribution in rice shoots. Plant Cell 20 (5), 1381-1389.

Yamaji, N., Chiba, Y., Mitani-Ueno, N., Ma, J.F.,2012. Functional characterization of a silicon transporter gene implicated in silicon distribution in barley. Plant Physiol. 160 (3), 1491-1497.

Yin, J., Yang, X., Zheng, Y., 2014. Influence of increasing combustion temperature on the AMS 14C dating of modern crop phytoliths. Sci. Rep. 4.

Yost, C.L., Jackson, L.J., Stone, J.R., Cohen, A.S., 2018. Subdecadal phytolith and charcoal records from Lake Malawi, East Africa imply minimal effects on human evolution from the 74 ka Toba supereruption. J. Hum. Evol. 116, 75-94.

Zeller, B., Brechet, C., Maurice, J., Le Tacon, F., 2007. 13C and 15N Isotopic Fractionation in Trees, Soils and Fungi in a Natural forest Stand and a Norway spruce Planta-tion. Annals of Forest Science, 64. Springer Verlag, Germany, pp. 419-429, 4

Zhalnina, K., Louie, K.B., Hao, Z., Mansoori, N., da Rocha, U.N., Shi, S., Cho, H., Karaoz, U., Loqué, D., Bowen, B.P., Firestone, M.K., 2018. Dynamic root exudate chemistry and microbial substrate preferences drive patterns in rhizosphere microbial community assembly. Nature microbiology 1.

Zuo, X., Lu, H., Zhang, J., Wang, C., Sun, G., Zheng, Y., 2016. Radiocarbon dating of prehistoric phytoliths: a preliminary study of archaeological sites in China. Sci. Rep. 6.

Zuo, X., Lu, H., Jiang, L., Zhang, J., Yang, X., Huan, X., He, K., Wang, C., Wu, N., 2017. Dating rice remains through phytolith carbon-14 study reveals domestication at the beginning of the Holocene. Proc. Natl. Acad. Sci. 114 (25), 6486-6491. 